Document downloaded from:

http://hdl.handle.net/10251/72609

This paper must be cited as:

Hervás Oliver, JL.; González, G.; Caja Meri, P.; Sempere-Ripoll, F. (2015). Clusters and Industrial Districts: Where is the Literature Going? Identifying Emerging Sub-Fields of Research. European Planning Studies. 23(9):1827-1872.

doi:10.1080/09654313.2015.1021300

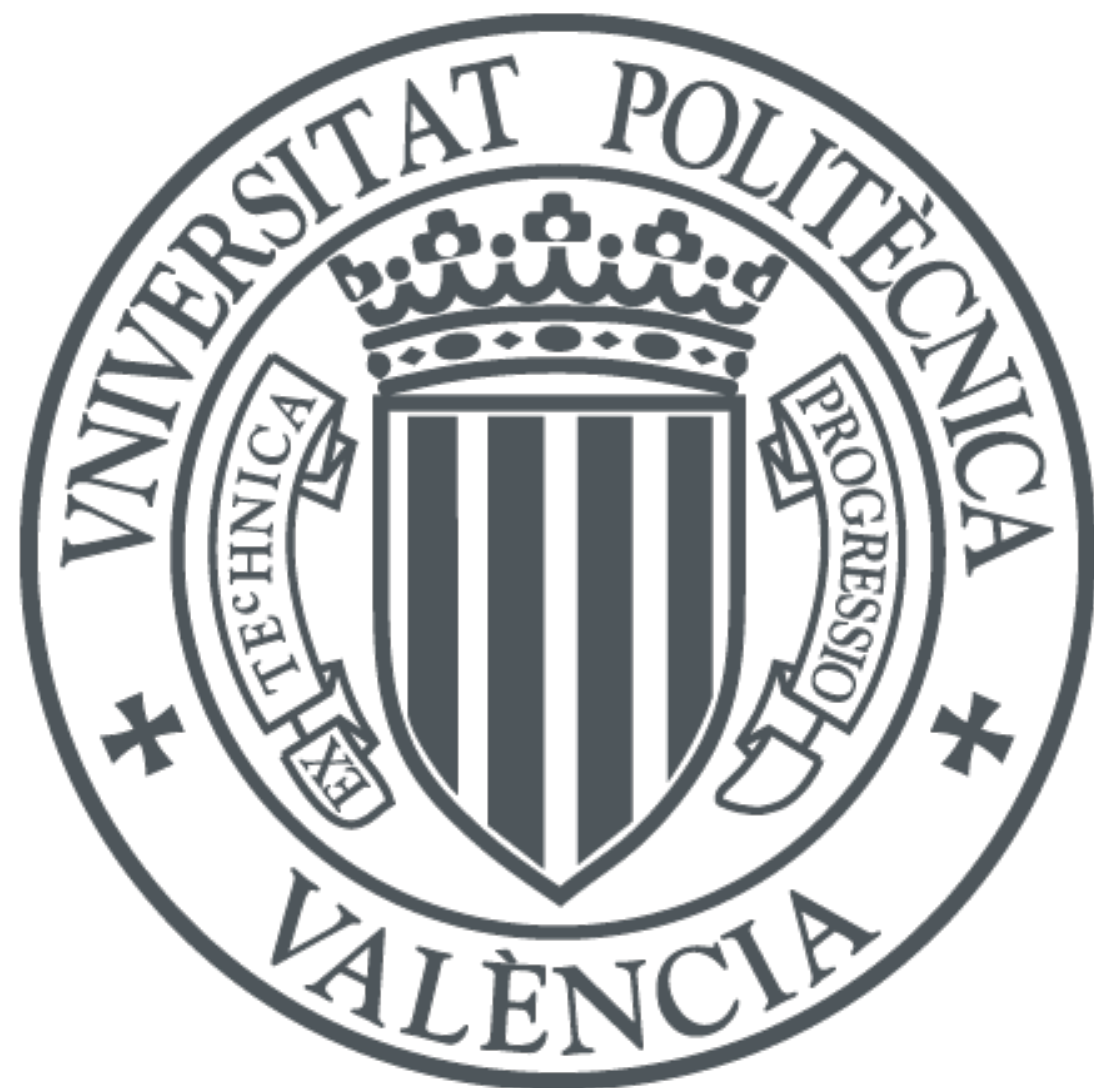

The final publication is available at

http://dx.doi.org/10.1080/09654313.2015.1021300

Copyright Taylor \& Francis (Routledge)

Additional Information

This is an Author's Accepted Manuscript of an article published in Jose-Luis Hervas-Oliver, Gregorio Gonzalez, Pedro Caja \& Francisca Sempere-Ripoll (2015) Clusters and Industrial Districts: Where is the Literature Going? Identifying Emerging Sub-Fields of Research, European Planning Studies, 23:9, 1827-1872, available online at:

http://doi.org/10.1080/09654313.2015.1021300 


\section{INGENIO WORKING PAPER SERIES}

\section{ingenio \\ Institute of innovation and knowledge}

management

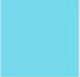 \\ Clusters and industrial districts: where is the literature going? Identifying emerging sub-fields of research}

Jose Luis Hervas Oiver, Gregorio Gonzalez and Pedro Caja

Working Paper № 2014-09 


\title{
Clusters and industrial districts: where is the literature going? Identifying emerging sub-fields of research
}

\author{
Jose Luis Hervas Oliver ${ }^{a, 1}$, Gregorio Gonzalez ${ }^{b}$ and Pedro Caja ${ }^{c}$ \\ ${ }^{a}$ Universitat Politècnica de València \\ ${ }^{\mathrm{b}}$ Universitat de València \\ ${ }^{\mathrm{c}}$ Universidad Cardenal Herrera-CEU
}

\begin{abstract}
The industrial district and cluster literature has generated an extraordinary quantity of articles, debates, and topics for discussion, and encompasses one of the most vibrant lines of research in the field of economics, geography, management and related disciplines. The literature, however, is fairly fragmented. In this paper, bibliometric methods are used to analyze cluster literature published between 1957 and 2014 in order to explore prospective research priorities through the method of bibliographic coupling. Beyond focusing on foundational works in the past, this approach shifts the focus away from the practice of analyzing co-citations and seminal contributions to one of looking at current and emerging trends in the literature. Using the ISI-Web of Knowledge (Web of Science) as a database, examination of two samples of 3,955 and 2,419 articles is made. Results reveal the existence of sub-fields of inquiry that are following their own particular research agendas, which remain distinct yet interconnected to one another.
\end{abstract}

Keywords: cluster, industrial district, bibliometric analysis, Web of Science, bibliographic coupling.

JEL Codes: R1

\footnotetext{
${ }^{1}$ Universitat Politècnica de València, Management Dept. Campus vera s/n, 7D DOE

46022 Valencia (Spain)

Telf. +3496387 7680 Fax. +34 963877689

Jose.hervas@omp.upv.es
} 


\section{Introduction}

Beginning with Marshall (1920), followed by Becattini (1979; 1990), Piore and Sabel (1984), Saxenian (1990), Krugman (1991) and Porter (1990), among others, the ideas of clusters/industrial districts ${ }^{2}$ have evolved within different disciplines, approaches and using different units of analysis. All perspectives have emphasized the influence of location on performance.

The fast rate at which the number of publications on clusters is increasing, together with the variety of methodologies and perspectives employed, plus the size of the range of topics addressed, all make for difficulty in keeping track of the evolving literature on the subject. Recent contributions notwithstanding (e.g. Lazzeretti et al., 2014; MartinezFernandez, Capo-Vicedo and Vallet-Bellmunt 2012; Cruz and Teixeira, 2010), the cluster literature has seen very few objective bibliometric reviews carried out on it. Moreover, all those works which have reviewed the literature - tracing intellectual origins, producing a history of founders, or highlighting the most cited papers (e.g. Lazzeretti et al., 2014; Cruz and Teixeira, 2010) - have provided retrospective accounts by using direct citation counts and co-citation analysis. While scholars have become quite active in that literature, this remains rather fragmented, finding key contributions in economics, management or economic geography strands. These conversations sometimes are even disconnected from each other. This gap calls for a prospectively detailed and objective review of the literature in order to better understand the current state of the field and to provide some guidance for future research. In particular, our main goal consists of identifying emerging topics or lines of inquiry in the literature using bibliometric techniques.

In this paper, however, we leave retrospective co-citation analysis to others and suggest a different approach. This paper introduces to cluster scholars the method of bibliographic coupling (Kessler, 1963); this complements traditional co-citation analysis by enabling a different kind of analysis based on looking at current trends or emergent topics in the cluster literature. Thus, by applying bibliographic coupling this paper is able to detail in the cluster field current thematic expansions and diversifications, with the purpose to

\footnotetext{
${ }^{2}$ We recognize differences among them (see e.g. Asheim et al., 2011 for differences between "clusters” and "industrial districts”), but both concepts are used interchangeably in this paper and represent our focus
} 
understand the current state of the field and its emerging conversations. This approach allows us to look to the future and consider the prospect for different research areas. Besides, our work perfectly complements constructively those previous works focused on retrospective accounts. In this paper, we focus particularly on cluster/industrial districts. The assessment and synthesis should make this field of research clearer to scholars, contributing to its integration and thus permitting a better diffusion among the scientific community.

Bibliometric tools are particularly useful in precising magnitude and dynamics of the cluster literature. Bibliometric tools and surveys permit an objective assessment of emerging topics (prospective) and seminal contributions (retrospective). A structured analysis and quantitative approach to the literature through the application of citation analysis provides rigor, objectivity and a capacity for synthesis. In short, co- citation analysis and direct citation analysis used in previous works (e.g. Cruz and Teixeira, 2010) either trace the intellectual roots of the field by identifying foundational works, and so in this regard are past oriented (Gregoire et al., 2006), or measure the impact of publications. In contrast, bibliographic coupling detects current trends and future priorities as reflected by what is happening at the forefront of research, and measures publication activities or current production, rather than impacts, and shifts the focus away from past achievements to current trends (Vogel and Güttel, 2013). This serves to supplement rather than substitute for the results obtained using traditional co-citation methods (Jarneving, 2005). Bibliometric techniques and surveys complement those more qualitative surveys (e.g. Breschi and Lissoni, 2001; Malmberg and Maskell, 2002). Besides, the introduction of the bibliographic coupling method is a promising research tool for cluster scholars.

This paper positions itself at the forefront of debate in the industrial district and cluster field. It contributes to the literature by systematically reviewing current research trends, academic discourses, and the expansion of specific theme focused research communities. In doing so, the paper complements previous qualitative analysis, and also bibliometric works using different techniques and objectives. Besides, a key feature of this study is that it is based on an accessible database (Web of Science), allowing replication and extension by other scholars who can extend or replicate results. To avoid a reference bias, our point of departure is the totality of documents about clusters/industrial districts listed in the ISI Web of Knowledge (Web of Science) between 1957 and 2013. For this 
reason, we run keyword queries to identify all scholarly articles published in refereed journals: 3,955 and 2,419 documents in two searches, covering more than 300,000 references on them. Our results delineate the conceptual and thematic boundaries of the cluster field, while differentiating between distinct but interrelated sub-fields or thematic groups of thought within it. In our view, the hitherto absence of the use of coupling analysis in the cluster field makes this research timely, complementing as it does previous research on the cluster concept's intellectual evolution. The article is structured as follows. Section 2 describes our methodological approach to mapping current trends in the field. Then, Section 3 presents our research design, data analysis and results. Section 4 extends empirics with a second search of documents. Finally, Section 5 provides our main conclusions and sets out future research avenues. One Appendix with additional data is also included.

\section{Methodological approach: bibliographic coupling}

There have been less bibliometric works identifying emerging topics or current existing knowledge areas within a discipline than there have been traditional studies focused on past citations or literature impact (Boyack and Klavans, 2014). Scientific research on a particular subject is concerned with the process of new knowledge generation, and as such it stands on, and departs from, pre-existing knowledge. The use of bibliographic references is the mechanism by which new knowledge is linked to earlier knowledge. The study of bibliographic references in scientific documents enables reconstruction of the intellectual process through which new knowledge is generated; serves to identify current knowledge areas; and determines the roles and influence of documents in subsequent literatures. In all, there are three methods used for identifying and analyzing bibliographic references: direct citation, co-citation analysis, and bibliographic coupling (Yang and Ding, 2012).

The most extensively used method is that of direct citation. This method produces highly visible and well recognized indicators such as the h-index or the impact factor. Thus, the higher the number of citations a document receives, the higher the impact the document is said to have on a scientific community. In figure 1 , document 1 directly cites document 3. Thus, document 3 accumulates citations. Co-citation analysis, however, is focused on 
quantifying how frequently a pair of documents is cited together in the literature. This enables the study of the influence of the cited documents; permits analysis of the interrelationships between the cited documents; and enables the identification of the most influential founders (cited documents and authors) in a discipline. In figure 1, documents 2 and 3 or 2 and 5 are co-cited, that is, they are jointly listed in the same list of references. Both methods, however, only provide a retrospective vision, informing how research has evolved over time. For this approach it is necessary for analysis to cover long time windows in order to be able to identify whether particular documents have been later browsed, or cited in subsequent studies (Gmür, 2003). See figure 1.

\section{Figure 1 about here}

A different focus and approach is offered by bibliographic coupling. This methodology identifies and quantifies those cases where documents cite the same references. The rationale is that documents that cite (citing documents) the same publications can be assumed to be related, and the higher the number of shared references then the greater the thematic proximity between them. Bibliographic coupling permits the identification of active research activities within a discipline or scientific field, and is a prospective method. In figure 1 document 1 and document 4 both cited document 2. Both documents share a same reference (document 2) and, therefore, share a similar thematic focus, provided that they share a minimum number of references. See figure 1 for a graphic representation of bibliometric techniques. In bibliographic coupling the focus is the citing documents (1 and 4), whereas in retrospective techniques the focus is on the cited documents ( 3 in direct citation or 3 and 2 in co-citation).

The citing documents sharing the same literature references are defined as similar, and as being involved in the same scholarly discourse. Besides, this method permits to incorporate to the debate current production not cited yet. For instance, suppose that the document 4 has itself not yet necessarily been cited, due to its recent publication. To incorporate document (4) in other methodologies such as co-citation would require waiting a long period of time until it is cited by other documents (Jarneving, 2007). In bibliographic coupling this new document (4, following the example) can be clustered into a thematic discourse or line of research, permitting thus to analyze emergent trends or shifts in that particular sub-fields of inquiry. 
Bibliographic coupling refers to the number of references shared by at least two (citing texts) documents, with the greater the number of references (cited texts) directed to the same documents then the greater said to be the similarity between the citing documents. For instance, if citing papers A and B, both published in 2013, cite Marshall (1920), these two citing documents are presumed to be similar because they both refer to the ideas of clusters. Then, if both citing papers A and B also cite Cohen and Levinthal (1990) and Giuliani (2013), then both documents A and B are said to be similarly addressing not only clusters, but also the themes of absorptive capacity and network analysis or technology gatekeepers, respectively. In contrast, if citing documents $\mathrm{C}$ and D, published in 2013, also cite Marshall (1920), but then also cite Jacobs (1969), Frenken et al., (2007), and Boschma, Miranda and Navarro (2012), then this indicates that $\mathrm{C}$ and $\mathrm{D}$ are coupled to (i.e. have a similarity orientation to) the sub-field, or scholarly conversation of, related variety, a subject which remain interconnected yet distinct to previous $\mathrm{A}$ and $\mathrm{B}$, forming a different scholar conversation within the wide theme of agglomerations. Documents A, B, C and D are the "citing" documents which are the unit of analysis in bibliographic coupling. Notice that these are not necessarily seminal documents, but represent emerging or current production in the field. The latter represents this paper's purpose. On the contrary, their shared references (e.g. Cohen and Levinthal, 1990) are the "cited” documents and they are usually seminal contributions. Grouping “citing” documents within sub-fields of inquiry requires a minimum amount of same shared references (cited ones) or bibliographic threshold, as explained below. See figure 2 illustrating briefly the above example.

\section{Figure 2 about here}

As shown below, a pair of documents (or nodes) are grouped together as belonging to a sub-field of research only when they share a minimum number of references, usually no less than 10 (Glänzel and Thijs, 2012; Small, 2009), in order to secure consistency on the theme. Adherence to a minimum ensures a sufficient level of similarity (see Appendix). Those "citing" documents identified as reaching a sufficient level of similarity are defined as core documents belonging to a sub-group, a sub-field of inquiry, a hot research topic, or a scholarly discourse within a particular field. A core sub-group has high cohesiveness and dense interconnections between members, and weak connections to non-members within the field. Besides, statistically some parameters have also to show consistent statistically significance when identifying sub-fields. Thus, sub-groups 
are distinctly distinguishable from the rest of the field. The members or documents of each sub-group or sub-field are highly cohesive and pursue their own research agenda independently from other discourses within the field (Vogel and Güttel, 2013).

\section{Research design, data analysis and results}

\subsection{Empirical design}

Our method is rooted in bibliometrics (Garfield, 1955; Shibata et al., 2008; Boyack and Klavans, 2010). Making sense and organizing a vast amount of literature requires making decisions in respect of the search criteria or key words utilized. In order to achieve a complete coverage of the literature and avoid a reference bias, we run keyword queries twice. The keyword queries try to identify all scholarly articles published in refereed journals. Using different key words allow a more comprehensive search. A first and initial broad search in the ISI Web of Kowledge was undertaken through the TOPIC criteria [those documents mentioning “industrial district*” OR “cluster*”], and by then further restricting the output to the BUSINESS, ECONOMICS, ENVIRONMENTAL STUDIES, GEOGRAPHY, MANAGEMENT, PLANNING DEVELOPMENT and URBAN STUDIES fields within the ISI Web of Knowledge. The dataset was then checked for authors who use the words "cluster*" or "industrial district*". Then, after cleaning the dataset obtained ${ }^{3}$ we listed a sample composed of 3,955 documents (mostly articles) which included 202,732 cited references, covering the 1957-2013 period ${ }^{4}$. Every document received a numeric code in order that it could be identified throughout the study. Every document is a citing text and it contains cited (its references) ones. We focus on "citing” texts, albeit using their shared references or cited documents in order to classify and get sub-fields of inquiry. In the Appendix a list of the most cited references in that first search is listed (see table A-1 in Appendix).

\footnotetext{
${ }^{3}$ For instance, we identified hundreds of documents which said they were applying "cluster (statistical) techniques", while others made reference to clusters of star constellations.

${ }^{4}$ We search for 1900-2014. The first paper meeting our requirements was in 1957. Interestingly, the search identified articles during the 1950s and 1960s, such as CRIBIER F. (1966), Industrial Districts of East-End of London, Annales De Geographie , 75: 208-209.; NAZAROV Y. (1962), The Problem of Organizing a Food-Supply Base for the Yeniseysk Industrial District, Soviet Geography Review and Translation , 3: 45-55.; WAGNER C. (1957), Planned Industrial Districts, Journal of Geography , 56: 129-132.; WEISS S., KAISER E. (1968), Quantitative Evaluation of Major Factors Influencing Urban Land Development in a Regional Cluster, Ekistics , 25: 338-342
} 


\subsection{Results from the first search}

A first outcome of our bibliographic coupling analysis was the production of an aggregated matrix that displayed for all document pairs the co-occurrence of shared references in their bibliographies. This similarity matrix was then subsequently processed for detection of homogeneous groups, using multivariate statistical and network analysis for visualization. In social network analysis, communities are groups of nodes that are more intensively connected to one another than to the rest of the network; this serves to identify particularly cohesive sub-structures which represent specific subfields or research lines within the cluster literature. These communities of nodes (citing documents) share references around a core concept or topic within the field of research, as explained above.

Starting with the matrix that shows the frequency with which pairs of documents share references, then partial clustering algorithm technique on frequency counts is applied. This serves to cluster progressively the pairs of papers sharing references (Persson, 1994), and thus the different thematic discourses (documents sharing references) that are identified are individually labeled. A minimum threshold of the sharing of 16 references is fixed and, after applying partial clustering technique, results categorized 129 documents into six groups. Then, for visualization purposes we use network analysis. Figure 3 below presents the sub-fields identified for the period 1957-2013. In the network obtained through bibliographic coupling more than $3 \%$ of the total documents are included, a value well above the minimum $1 \%$ recommended by the literature ${ }^{5}$ (e.g. Glänzel and Thijs, 2012). All citing documents which did not show similarity between each other by citing a threshold of references were not coupled. Then, we proceed to read and review content in all coupled documents. See figure 3 and table 1 for a summary of results. In table 1 we analyzed also the cited (shared) references in the 129 citing documents, in order to understand each group more comprehensively. Table 2 lists all articles by thematic groups showed in Figure 3. See table1and 2.

\section{Insert figure 3 here}

\section{Insert table 1 here}

\footnotetext{
${ }^{5}$ Following Glänzel \& Czerwon (1996, 1995), common studies represent at least $1 \%$ of the initial population of documents. In our study, we used 3.38\% (threshold of 16 shared references) in our sample, represented in the network of bibliographic coupling in the figure 3 .
} 


\section{Insert table 2 here}

In the network of bibliographic coupling presented in figure 3 we have identified six groups currently focused on particular sub-fields in the cluster literature. These six groups are shown again in table 1, together with the proposed thematic titles for the discourses they are focused on. Included in table 1 are the symbols the groups are identified by in figure 3, along cited references, journals where the citing documents are published and other additional information.

Thanks to the bibliographic coupling technique, the network presented in figure 3 for the most part provides papers published in the 2000s, showing the current state-of-the-art and emergent yet consolidated sub-fields. We insist on the fact that the documents visualized only represent current or emerging scholar conversations, not constituting seminal or foundational works per se. These groups are analyzed as follows.

Group 1 has within it those works related to the evolutionary economic geography discourse (e.g. Frenken and Boschma, 2007; Martin and Sunley, 2006; Boschma and Frenken, 2006), including cluster evolution and path dependency (Mackinnon et al., 2009; Henning et al., 2013; Maskell and Malmberg, 2007; Menzel and Fornahl, 2010). Textual analysis found that key words or phrases used by the group included, for example: “evolution/evolutionary”, “path dependence” or "path creation”. This group focuses on describing evolutionary economic geography, considering aspects such as the co-evolution of firms, industries, networks (Ter Wal and Boschma, 2011) and clusters in space (Menzel and Fornahl, 2010); the debate on related variety (Neffke et al., 2011); and geographical explanations for path dependency or myopia (Martin, 2010; Martin and Sunley, 2006; Maskell and Malmberg, 2007, among others). As explained below, the specific topics within it cannot be captured only by using our search strategy (keyword = industrial district* and cluster*) in the ISI Web of Knowledge, provided that multiple sub-topics are represented within the evolutionary economic geography discourse, as indicated by Boschma and Frenken (2011). We extend this group in Section 4.

A second sub-field, Group, 2, concerns itself with the theme of global pipelines or external linkages, connecting clusters to the outside world and explicitly recognizing that external linkages, beyond local buzz, are also development mechanisms. In this line of thought, this group has been particularly influenced by Bathelt et al.'s (2004) seminal work on the definitions of global pipelines and that of temporary clusters in global 
pipelines (Maskell et al., 2006). The most cited papers are indeed Bathelt et al., (2004), as well as Malmberg and Maskell (2002). This emergent and highly cohesive sub-group focuses on revisiting localized (as opposed to national or international level) learning (Lorenzen, 2007), and locations as places for knowledge creation (Malmberg and Maskell, 2002). This group is supported by management and economic geography-based literature on the cluster topic that recognizes the benefits from openness in clusters ${ }^{6}$.

Group 3 is focused on the topic of cluster taxonomies, that is, on the subject of defining ideal types or taxonomies of spatial industrial clustering. Core papers highlight the different types of clusters and other related conceptualizations (e.g. Gordon and McCann, 2000; Iammarino and McCann, 2006). The most cited paper is that of Gordon and McCann (2000). This is smallest group in terms of number of documents. It is also the one that seems to be more static.

A fourth group, Group 4, has the thematic title "innovation and firm analysis" and is concerned with innovation-related studies. In this group management/business journals, concepts and even authors are highly represented in the cited references listed in citing documents. In this numerous and heterogeneous group, there is an emphasis on empirical research on the role of firms in clusters and industrial districts and their strategies based on leveraging localization economies. Common concepts referred to include: capabilities, strategy (e.g. Belussi and Sedita, 2009; Belussi et al., 2008; Camison, 2004; Camisón and Villar-Lopez, 2012) and knowledge (Malecki, 2010ab); absorptive capacity (Hervas-Oliver and Albors-Garrigos, 2009); and innovation and/or firm performance (e.g. Hervas-Oliver et al., 2012; Molina-Morales and Martínez-Fernandez, 2003). Most of the shared references of this group are for papers concerned with managerial capabilities and absorptive capacity (Cohen and Levinthal, 1990). Overall, this group encompasses a diversity of topics based on innovation studies and using a managerial approach by which the core unit of analysis are cluster firms, their strategies and capabilities to use and exploit external (to the firm) knowledge. Besides, most of those scholars are based at the intersection between economic geography and management.

\footnotetext{
${ }^{6}$ In line with this idea of clusters opening to new knowledge, Markusen (1985) states that inward-looking orientations impact negatively on cluster performance, whereas openness of networks to new skills, knowledge and firms have positive influences (Porter, 1998; Bresnahan et al., 2001; Romanelli, E., Khessina, O.M., 2005; Eisingerich et al., 2010). Besides, from the management perspective Arikan's (2009) framework, based on Rosenkopf and Almeida (2003), also posits that the more cluster firms engage in knowledge exchanges with outside entities, the stronger the creation of new knowledge in clusters becomes.
} 
Despite addressing micro-level and firm-based concepts, regional-based journals are prominent in this group, such as European Planning Studies, Entrepreneurship and Regional Development or Regional Studies, among others.

Group 5 has as its central theme that of inter-firm networks, social capital and flows of knowledge within networks and clusters, again being mainly based at the firm-level and using extensively management concepts. In this group, the literature focuses on networks and their evolution, using a spatial dimension from the economic geography (e.g. Gluckler, 2007) together with a management perspective in which joint effects of geographic proximity and network position, concurrently, are analyzed and their effects on organizational innovation (Whittington, Owen-Smith and Powell, 2009). Several disciplines address this line of research. For example, a managerial perspective addresses the role of social capital in networks (e.g. Inkpen and Tsang, 2005), network evolution (Rosenkopf and Padula, 2008), networks of innovation (Belussi, Samarra and Sedita, 2008) and knowledge creation in clusters (Arikan, 2009). Besides, a regional-based approach refers to subjects such as social capital in regions and clusters (Malecki, 2012) or knowledge evolution (Huggins, 2008) concepts. Again, this group has strong connections with the management literature, journals and authors, in a similar way to that of Group 4, “innovation and firm analysis”. In the Group 5 management and business/innovation journals (e.g. Organization Science, Academy of Management Review, Administrative Science Quarterly, Research Policy, Technovation, Journal of Business Research, Innovation-Management Policy \& Practice) co-exist with those economic geography dedicated, such as Journal of Economic Geography, Regional Studies or Entrepreneurship and Regional Development, among others. Besides, empirical citing documents utilize extensively network analysis methodology. In this group it is also observed profound theoretical reviews of social capital, indistinctively in management (e.g. Inkpen \& Tsang, 2005, Arikan and Schilling, 2011) and economic geography/regional studies journals (e.g. Malecki, 2012). Knowledge creation in clusters (Arikan, 2009) and cluster functioning and performance, using social network theory for depicting innovation in clusters (Eisingerich et al., 2010), are also present in this group.

Lastly, Group 6 shows a common interest in the emerging theme of spatial network analysis as a methodology for investigating clusters, similar to that in Group 5, including knowledge exchange among cluster firms (Giuliani, 2007; Giuliani, 2013) and the role of technology gatekeepers (TGs) and their positions in networks (e.g. Morrison et al., 
2013; Morrison, 2008; Kesidou and Snijders, 2012). This TGs and network-position analysis group seeks to explore the structural properties of networks and the circulation of innovation related knowledge at the cluster firm level, stressing the role of TGs. In this group the journals are mainly those from the regional studies/economic geography and present a clearer tendency to position debate in understanding spatial clusters as complex set of networks in which central positions are occupied by TGs (Allen, 1977) restricted to their meaning in the context of cluster literature (see Bell and Albu, 1999 and Giuliani and Bell 2005).

It is particularly worth highlighting that the groups 4, 5 and 6 are highly connected to one another, but less so to group 3, and even less so to groups 1 and 2. In fact, as observed in the Figure 1, Belussi and Sedita (2012) act as a connector of the three groups. Moreover groups 4, 5 and 6 tend to be published in different journals than groups 1, 2 and 3. As above mentioned, Groups 4,5 and 6 are not only to be found in major journals such as European Planning Studies and Regional Studies, but also have a very prominent presence in managerial journals, such as Organization Science and Academy of Management Review, and in publications devoted to technology and innovation, such as Research Policy or Technovation. In contrast, groups 1, 2 and 3 are more visible in economic geography and regionally focused journals, such as Economic Geography, Journal of Economic Geography, Regional Studies or Environment and Planning A, among many others, and draw less on managerial concepts. See table 1 for a brief synthesis. For the sake of brevity, more results available upon request.

In short, the careful analysis of bibliographic networks has clearly revealed the existence of a core sub-network of sub-groups: 4 (innovation and firm analysis), 5 (inter-firm networks, social capital and flows of knowledge) and 6 (network analysis and technology gatekeepers). This sub-network is highly influenced by classic managerial concepts, such as gatekeepers, absorptive capacity, firm strategy or knowledge but also by traditional cluster/economic geography ideas such as social capital, or other topics shared in the last years by both management and economic geography perspectives, like network analysis and networks of innovation. Overall, those particular scholar conversations addressing clusters are highly influenced by management and innovation perspectives and approaches. Besides, it has also been observed that there are two emergent dynamic and prolific sub-fields, addressed by groups 1 (evolutionary economic geography) and 2 (global pipelines), that are moving the cluster discourse beyond the 
classical topics observed in the traditional core of the literature. It is important to stress the fact that some sub-groups can also overlap in particular topics but each sub-field pursuit rather different research agendas. For instance, groups 4 (innovation and firm analysis), 5 (inter-firm networks, social capital and flows of knowledge) and 6 (network analysis and gatekeepers) all share, in general, the focus on analyzing firms or plants, as unit or level of study, in clusters. Lastly, of particular interest is the movement of the management approach and its analysis at the firm level into the economic geography field, as can be seen especially in the cases of group 4 (innovation and firm analysis) and 5 (inter-firm networks and social capital). Of further note is the increasing popularity of methodologies connected to network analysis and statistics, found in group 5 and 6.

\subsection{Additional insights}

It should be pointed out that table 1 and figure 3 does not include key past or foundational works as citing documents, what might be referred to as seminal founders, nor incorporate traditional seminal works (such as Saxenian, 1994 or Becattini, 1990, among many others showed in Table A-1 in the Appendix). The reason for that is that bibliographic coupling does not search into the retrospective literature but current or emergent production: its tracks current (ongoing production) scholarly discourses solely focus on clusters/industrial districts and not analyzes historic intellectual foundations, as Cruz and Teixeira (2010) or Lazzereti et al., (2014) do. For this reason, our paper's results differ from those. An interesting but different point, however, is that these discourses are in fact rooted (as shown in the shared references in table 1) in the seminal works of each sub-field, as explained further below. Other related debates (and their foundational works) such as regional innovation systems or learning regions are not showed because they are out of this paper's scope ${ }^{7}$ and they cannot be found using the mentioned search strategy based on those particular keywords. This does not mean they are not important for the regional studies or the economic geography, but we follow the above mentioned scope based on clusters and industrial districts. See figure A-1 in the Appendix.

Figure A-2 in the Appendix shows the growth of the cluster/industrial district field according to the number of publications coming out each year, over the period 1957-

\footnotetext{
${ }^{7}$ According to ISI Web of Knowledge, Morgan, Gertler, Grabher, Cooke, Maskell, Malmberg, Florida, Asheim or Pinch, among others, are seminal authors in that conversation.
} 
2013. Growth has been impressively prominent since the beginning of the 1990s. Only in 2011 more than 400 documents addressing industrial districts and clusters are observed. See figure A-2 in the Appendix.

The 3,995 articles from the first search were published in multiple journals. For the sake of brevity, we show the first twenty academic journals. The distribution among the journals is, however, quite skewed. Taking at least one hundred papers published as a cut-off point, we are left with only four journals: European Planning Studies, Regional Studies, Urban Studies and Environment and Planning A. Taking at least seventy papers published as a cut-off point, we are left with five, additional to the previous ones, journals. These new ones are Research Policy, International Journal of Technology Management, Entrepreneurship and Regional Development, Technological Forecasting and Social Change and Journal of Economic Geography. As observed, those publishing at least one hundred, along with Journal of Economic Geography, are considered as specialty or niche journals (e.g. European Planning Studies, Journal of Economic Geography), whereas the rest are multidisciplinary journals devoted not only to clusters but to innovation, entrepreneurship or technology management. This fact is a good indication of the cross-disciplinary content of the field and the diversification into different conversations or communities. See figure A-3 in the Appendix.

The final 129 citing documents from the bibliographic coupling exercise were published in forty academic journals, showing a slightly different distribution of journals, in respect of figure A-3. See figure A-4 in the Appendix. As observed in figure A-4, the toppublishing ten journals account for $70 \%$ of the citing documents. With the exception of Entrepreneurship and Regional Development, Technovation and Research Policy, all the top-publishing journals are considered to be specialty or niche ones. The rest of journals are mixed, with specialty ones mostly focus on broad regional studies (e.g. Papers in Regional Science), management and business ones (e.g. Journal of Management Studies, Academy of Management Review) or innovation/technology ones (e.g. Industry and Innovation, Industrial and Corporate Change). Findings from Figure A-3 and A-4 show how fragmented is the focal literature. For the sake of brevity, more results available upon request. 


\subsection{Empirical extension: second search}

The initial search strategy [industrial district* and cluster*], however, represents a limitation in itself, provided that there can be more documents in the literature addressing clusters or industrial districts beyond that particular search strategy or keyword query. With the purpose to detect emergent topics or current research lines within the cluster/industrial district topic, not previously captured in our initial search, and with the purpose to triangulate results, a new search based on a different keyword query complements the previous one and assures not to leave additional documents out.

In order to achieve a more complete coverage of the potential literature around industrial district and cluster topics, a second search in the ISI Web of Kowledge ${ }^{8}$ was undertaken through the TOPIC criteria [keyword $=($ agglomeration $*)$, restricting documents within BUSINESS, ECONOMICS, ENVIRONMENTAL STUDIES, GEOGRAPHY, MANAGEMENT, PLANNING DEVELOPMENT and URBAN STUDIES fields within the ISI Web of Knowledge, obtaining 2,419 citing documents. The most shared references in those citing documents from the second search are presented in table A-5. New documents were analyzed, provided that our paper's scope is restricted to industrial districts and clusters. Using a similar methodological criteria and statistics, new documents are clustered into groups and their content was carefully revised. In this second search, groups which were already represented in the first search and new ones, not previously showed in the initial search, were identified. A fuzzy set of different groups was observed. These new groups mostly addressed economics of agglomerations, along with other management and urban strands. In the table A-5 (see Appendix) the most cited (shared references) documents in the 2,419 works, that is, the references available in the new set of documents, are those based on Krugman, Glaeser, Venables, Jaffe, etc., with very active journals such as Journal of Political Economy, Quarterly Journal of Economics or the American Economic Review. After a detailed identification of documents, a leading group addressing economics of agglomerations stands out, with works from Puga, Ottaviano, Fujita, Krugman, among others. Obviously, this conversation was considered to be out of our scope ${ }^{9}$. The rest of groups were not related

\footnotetext{
${ }^{8}$ See Lazzeretti et al., (2014) for the limitations of the ISI Web of Knowledge and the ISI Web of Knowledge itself.

${ }^{9}$ In this group the journals are dedicated to the development of theory and methods in spatial economics and the economics of agglomeration, such as Journal of Regional Science, Spatial Economic Analysis,
} 
to clusters or industrial districts ${ }^{10}$, as they referred to urban economics or other different strands from those of clusters/industrial district topics ${ }^{11}$. There are two conversations from the agglomeration search, however, which content could be included in our paper' scope, provided that the specific lines of study address clusters/industrial districts and can also be interpreted within Group 1, suiting properly in our paper's scope. These two new topics were highly connected to Group 1 Evolutionary economic geography, referring to spinoffs and agglomeration and firm performance. Thus, and with the purpose to refine the search and address these new conversations, we extend the second search, addressing spinoffs and firm performance [keyword= (agglomeration* AND spin-off*/spinoff*) and (agglomeration* AND performance*)]. Following previous methodology, the network was constructed and the conversations’ content analyzed.

\section{Insert figure 4 here}

\section{Insert figure 5 here}

\section{Insert table 3 here}

As showed in figure 4 and 5, referred to spinoffs, the new documents address conceptually those topics based on evolution within Group 1, providing additional insight of specific debates within that sub-field of inquiry, as Boschma and Frenken (2011) have suggested: from an evolutionary perspective, clusters are analyzed by tracing regional entry and exit patterns over time through the study of spinoffs. Results for the spinoffs topic reduced the original set to 24 citing documents (figure 4), well integrated into one highly cohesive group, while agglomeration and firm performance topic (figure 5) showed 221 documents integrated in two final sub-fields of 27 and 14 documents. See figure 4 and 5 . Besides, table 3 lists all documents from figures 4 and 5.

The interpretation of the spinoff debate is really interesting. Generally, Boschma, Wenting, Buenstorf and Klepper, among others, lead this emerging conversation. We

Papers in Regional Science or Regional Science and Urban Economics, with a minor presence of others such as Regional Studies, or Journal of Economic Geography. Leading authors in the conversation are, among others, Puga or Fujita. Most cited and shared references in this sub-group are: Krugman P, 1991, V99, P483, J Polit Econ; Krugman P., 1991, Geography Trade; Glaeser EL, 1992, V100, P1126, J Polit Econ; Venables, 1999, Spatial Ec Cities Re; Jacobs J., 1969, Ec Cities; Marshall A, 1920, Principles Ec; Jaffe AB, 1993, V108, P577, Q J Econ

\footnotetext{
10 There is a small group of 11 papers addressing regional innovation systems, led by Todtling, Belussi or Doloreux, citing intensively at seminal authors like Cooke, Philip or Bjorn Asheim. Nevertheless, not all of them fit in our scope of clusters and industrial districts.

${ }^{11}$ For the sake of brevity, more results available upon request.
} 
observe in figure 4 an integration of literatures based on management/economics (Management Science, Journal of Evolutionary Economics, among others) and economic geography (Regional Studies, Journal of Economic Geography, among others). In respect of the content of the conversation, scholars have been elaborating how clusters are constructed through firm entry and exit, analysing differing types of new entrants (such as start-ups, diversifiers and spinoffs), and researching survival rates (e.g. Boschma and Hartog, 2014; Costa and Baptista, 2012; Klepper, 2011; Buenstorf and Klepper, 2009; Wenting, 2008; Klepper, 2007; Boschma and Wenting, 2007). Spinoffs are driven by a process of organizational reproduction and heredity, and successful firms have higher spinoff rates and their spinoffs outperform competitors. This is the Klepper's assumption. Most of these studies have shed light on the debate between the effects of spinoffs, lead by Klepper and colleagues, versus those of agglomeration, explained by firm interactions, in explaining cluster formation and evolution. Despite the fact that the two perspectives overlap, and that the two strands can be reconciled (e.g. Costa and Baptista, 2012; Boschma and Wenting, 2007) by virtue of the fact that spinoffs have been found to be important in the first stages of a cluster's evolution while the effects of agglomeration play a key role in more advanced stages, there remains unresolved tension between the perspectives which calls for further empirical research (e.g. Costa and Baptista, 2012; Boschma and Wenting, 2007). Most cited references, shared by the group, are: Klepper (2007:2005) or Agarwal et al., (2004), among others.

Then, as observed in figure 5, addressing agglomerations and performance, the first subgroup, at the top side, is composed of 27 documents and represents the agglomeration and firm performance debate or how firms access and take advantage of MAR agglomerations, as Boschma and Frenken (2011) have stated, following an approach based on management (journals such as Academy of Management Journal, Strategic Management Journal, Journal of Business Venturing, Administrative Science Quarterly, among others) and, to less extent, on economic geography and innovation studies perspectives (Industry and Innovation, Research Policy, Journal of Economic Geography, Regional Studies). Marshall (1920), Shaver and Flyer (2000), Porter (1990), Jaffe et al., (1993) and Audrestch and Feldman (1996), among others, were the most cited and shared references in the group. At the bottom side of the figure 5 , the remaining 14 documents offer an economic geography/regional studies/economics dedicated subgroup of inquiry, with seminal authors like Malmberg, Potter, Eriksson or Glasmeier, 
published in economic geography dedicated journals (Journal of Economic Geography, Environment and Planning A, Papers in Regional Science, among others). Glaeser et al., (1992), Jaffe et al, (1993), Krugman (1991), Storper (1989), among others, were the most shared references in those citing documents.

In terms of content, the management approach in figure 5 presents two interrelated and inconclusive debates. Despite substantial amounts of work on the relationship between localization externalities and firm performance, important issues (e.g. Baum and Mezias, 1992; McEvily and Zaheer, 1999; Decarolis and Deeds, 1999; Sorenson and Audia, 2000; Kenney, 2000; Owen-Smith and Powell, 2004; McEvily and Marcus, 2005; Bell, 2005; Gilbert et al., 2008; Whittington et al., 2009; McCann and Folta, 2011) remain unresolved and is far from conclusive. There are studies which have found localization has no effect or even negative effects on performance (e.g. Baum and Mezias, 1992; Sorenson and Audia, 2000, Stuart and Sorenson, 2003; Gilbert et al., 2008; Kukalis, 2010), while others have found the link to be positive (Decarolis and Deeds, 1999; Bell, 2005; Folta, Cooper and Baik, 2006; McCann and Folta, 2011). Another unresolved discussion has focussed on the potential asymmetric benefits for located firms. While it is agreed that not all firms benefit equally from being located in an agglomeration (e.g. Baum and Haveman, 1997; Shaver and Flyer, 2000; Chung and Kalnis, 2001; Canina et al., 2005; McCann and Folta, 2011; Rigby and Brown, 2013; Pe'er and Keil, 2013), some studies have concluded that knowledge-rich firms are the main beneficiaries(e.g. McCann and Folta, 2011), while others say that on the contrary it is knowledge-poor firms which gain the most (Shaver and Flyer, 2000). Finally, the economic geography conversation in figure 5, discusses the impact of labour market-induced externalities on firm performance (Eriksson and Lindgren, 2009) or impact of spillovers and knowledge flows on the firms' performance (Eriksson, 2011; Boschma and Weterings, 2005). Besides, theoretical debates addressing MAR and Jacobs externalities (Beaudry and Schiffauerova, 2009) or localization externalities (Malmberg and Maskell, 1999) are observed. In this sub-field of research there is a more ample consensus, vis-à-vis its management-based counterpart, about the positive effect of localization on a firm's performance.

Finally, it is worth to point out the differences between the first and the second search. In the first search (industrial district and clusters) the most cited or shared references of the 3,995 documents analyzed, are Porter, Bathelt, Nelson, Saxenian, Marshall, Martin, 
Markusen and even Cohen's and Levintahl's absorptive capacity, among others (see table A-1 in the Appendix). In the second search, however, Krugman, Glaeser, Venables, Ottaviano or Puga, among many others (see table A-5 in the Appendix) are the most cited. Overall, there is a high coincidence of cited (shared references) documents in the citing documents from both searches, albeit the mentioned differences, as they constitute the fundamentals of our literature.

\section{Conclusion}

Cluster and industrial district literature remains rather fragmented across different disciplines and topics. This paper's objective has consisted of identifying emerging topics or lines of inquiry in the literature in order to provide a better understanding of the current state of the field. In doing so, this paper has sought to introduce to cluster scholars the method of prospective bibliographic coupling (Kessler, 1963). This approach can complement the traditional method of retrospective co-citation analysis, using bibliographic coupling as a way of evaluating likely emergent research in the field of interest. It has done this by analyzing current research communities and emerging perspectives to identify areas of thematic expansion. To avoid a reference bias, this paper has utilized an accessible database (Web of Science) which permits other researchers to replicate or extend the analysis. This is of paramount importance for the development of the cluster conversation. This paper has limited its scope to industrial districts and clusters. Conclusions are, therefore, contextualized into that particular scope.

More specifically, this analysis contributes to the field of clusters by identifying research lines that indicate current trends towards further differentiation or diversification of the cluster field research agenda. Within the cluster field there exists theoretical and conceptual diversification, and it is clear from the bibliographic coupling evidence we have provided that there exist differing discourses and topic-based communities of practice focused on particular topics, methods and intellectual foundations within the field of study. In particular, the principal network of bibliographic coupling and its complementary ones demonstrated in the study reveal current trends of the literature and/or emergent topics in the field of study. In conceptual terms, it has been shown there is a high diversity of sub-topics and conceptual approaches within the field: evolutionary economic geography, global pipelines, cluster taxonomies, innovation and firm level 
analysis, inter-firm networks and social capital, and network analysis and technology gatekeepers. This results does not mean that there is a saturation point. Other related conversations can co-exist even across those ones, such as policymaking for clusters. Searching more sub-fields would require using multiple keyword queries.

This study has achieved a picture of the current state of the field by using a new methodology that goes beyond traditional reviews which focus only on backwardlooking co-citation analysis with the aim of identifying the subject's past history and its intellectual foundations. The use of bibliometric analysis enables researchers to reveal current lines of research and emergent priorities in the cluster field.

Overall, the following key points stand out: (i) there are distinct yet interconnected conversations shaping the current evolution of the cluster literature across different disciplines; (ii) the fertile diversification of the literature is represented in, at least, six specific sub-fields of research or lines of inquiry: each conversation presents its own shared (cited) references, is published in specific journals and addresses particular topics, constructs and approaches within the focal cluster topic; (iii) it is specially relevant the prominent intersection of the management ${ }^{12}$ discipline, with its journals, topics and approaches, with that of economic geography/regional studies; (iv) a remarkable adoption of managerial constructs and concepts by the economic geography community (e.g. absorptive capacity, technology gatekeepers ${ }^{13}$ ) is observed; (v) an increasing interest of the micro-unit of analysis (cluster firms) as a focal point in some of the conversations (especially Group 4, 5 and 6), complementing thus the meso-unit of analysis (more typical in Group 1, 2 or 3); (vi) the consolidation of statistical methodologies based on (spatial) network analysis (especially in Groups 6 and 5).

Bibliometric coupling utilizes a prospective lens which complements other approaches carried out before based on co-citation analysis to obtain a picture of the origin and development of the cluster concept (Cruz and Teixeira, 2010; Lazzeretti et al., 2014). Despite the different methodological approaches employed, our work agrees with the observations of Lazzeretti et al., (2014) about a trend towards diversification within the field of study and a relevant cross-disciplinary nature of the cluster concept, highlighting

\footnotetext{
12 Management in a broad sense: referring to technology strategy, management of technology (MOT), innovation, organizational learning, etc.

${ }^{13}$ Cohen and Levintahl (1990) and Allen (1977), respectively are seminal works in management whose concepts are now vastly used in economic geography mostly popularized by Bell, Giuliani or Asheim, among others.
} 
in particular the significant roles of both management and innovation perspectives in the field of clusters. Besides, our results are partially coincident in those by Cruz and Teixeira (2010: 1267) research themes, albeit the latter is restricted only to a particular journal, Regional Studies. In all, our results complement other results based on retrospective methods.

This article is not free from limitations. This paper is not covering all literature within regional studies and economic geography but focused solely on a narrow concept: clusters and industrial districts in a cross-disciplinary way. First, the selection of a database (Web of Science) and key words using English might exclude important works written, or listed in journals, or indexed in a different language. Second, the process of citation can be motivated by self-legitimization strategies or other purposes (see Bornmann and Daniel, 2008) rather than for purposes of drawing on prior knowledge. Bibliometrics in general, and specifically in our paper, cannot capture authors' reasons for citation. Third, and following Vogel and Güttel (2013), works providing longer bibliographies tend to establish a higher network centrality when compared to those employing fewer references. Fourth, the particular threshold chosen for the minimum number of shared references, the distance measure, and the statistical multivariate method selected for clustering items (documents) all influence the number of groups selected and final results and conclusions. Fifth, our own "qualitative” interpretation of the empirical results around sub-groups also might influence the conclusions of this paper. Finally, this paper does not address exhaustively all possible conversations about clusters, as above mentioned, due to the wide spectrum of the seminal topic itself and the search strategies limitation by using specific key words. The search strategies utilized in this work may prevent from finding different conversations, as showed in the new subfields found in the second search.

In all, it should be noted that despite the identification of the various sub-fields, there might yet still exist important content variety, or sub-fields, within each sub-group, as showed in the second search showed in figure 4 and 5. For instance, and following Boschma and Frenken (2011), other discourses within evolutionary geographies are those such as the type of agglomeration externalities variation according to the stage of the product lifecycle in an industry (Potter and Watts, 2010), the channels through which spillovers are expected to occur (Almeida and Kogut, 1999) or the role of institutions in evolutionary economic geography (Boschma and Frenken, 2006). Different search 
strategies and triangulation of results among them can further improve our knowledge on those specific conversations or bring other conversations onto the stage. This paper, however, offers a comprehensive picture of the ongoing debate on industrial districts and clusters, along with a methodology for expanding and researching on any specific conversation within the field of analysis. We expect that cluster researchers can benefit from this new tool.

In the future new studies can improve our understanding of the cluster field. Future bibliometric and other studies could explore in depth each of these sub-fields and their content in order to provide a complete narrative of the state of the art and the topics and research lines within each group. Another useful line of research could be to look at potential conceptual and research relationships between, on the one hand, perspectives on clusters or industrial districts and, on the other hand, work on regional innovation systems. Then, a different but key exercise would be to apply bibliographic coupling to authors and journals in order to identify schools of thought and communities of scholars connected to topics within the cluster field. Finally, in order to track the evolution of the sub-fields identified in this study further analysis will be required to test for resilience or fragmentation over time. 


\section{References}

Allen, T., 1977. Managing the Flow of Technology. Cambridge, MA, MIT Press.

Almeida, P., Kogut, B., 1999. Localization of knowledge and the mobility of engineers in regional networks. Management Science 45, 905-917.

Arikan, AT., 2009. Inter-firm knowledge exchanges and the knowledge creation capability of clusters. Academy of Management Review 34,658-676.

Arikan, AT., Schilling, MA., 2011. Structure and Governance in Industrial Districts: Implications for Competitive Advantage. Journal of Management Studies 48,772803.

Asheim B.T., Smith H.L., Oughton C., 2011. Regional Innovation Systems: Theory, Empirics and Policy, Regional Studies 45, 875-891.

Bathelt, H., Malmberg, A., Maskell, P., 2004. Clusters and knowledge: local buzz, global pipelines and the process of knowledge creation. Progress in Human Geography 28,31-56.

Baum, J.AC., Haveman, H.A., 1997. Love thy neighbor? Differentiation and agglomeration in the Manhattan hotel industry, 1898-1990. Administrative Science Quarterly 42, 304-338.

Baum, J. AC., Mezias, S. J., 1992. Localized competition and organizational failure in the Manhattan hotel industry, 1898-1990. Administrative Science Quarterly 37 (4), 580-604.

Beaudry, C., Schiffauerova, A., 2009. Who's right, Marshall or Jacobs? The localization versus urbanization debate. Res. Policy 38, 318-337.

Becattini, G., 1979. Dal settore industriale al distretto industriale. Alcune considerazioni sull'unita` di indagine dell'economia industriale. Rivista di Economia e Politica Industriale 1, 7-21.

Becattini, G., 1990. The Marshallian industrial district as a socio-economic notion. In F. Pyke, G. Becattini, W. Sengenberger (eds) Industrial Districts and Inter-Firm Cooperation in Italy. Geneva, Switzerland: International Institute for Labour Studies.

Bell, G. G., 2005. Clusters, networks, and firm innovativeness. Strategic Management Journal 26 (3), 287-295.

Bell, M., Albu, M., 1999. Knowledge systems and technological dynamism in industrial clusters in developing countries. World Dev. 27, 1715-1734.

Belussi, F., Sammarra, A., Sedita, SR., 2008. Managing long distance and localized learning in the Emilia Romagna life science cluster. European Planning Studies 16, 665-692.

Belussi, F., Sedita, SR., 2009. Life Cycle vs. Multiple Path Dependency in Industrial Districts. European Planning Studies 17,505-528.

Belussi, F., Sedita, SR., 2012. Industrial Districts as Open Learning Systems: Combining Emergent and Deliberate Knowledge Structures. Regional Studies 46,165-184.

Boschma, R., Frenken, K., 2011. The emerging empirics of evolutionary economic geography. Journal of Economic Geography 11, 295-307. 
Boschma, R.A., Frenken, K., 2006. Why is economic geography not an evolutionary science? Towards an evolutionary economic geography. Journal of Economic Geography 6,273-302.

Boschma, R., Hartog, M., 2014. Merger and Acquisition activity as driver of spatial clustering: the spatial evolution of the Dutch banking industry, 1850-1993.

Boschma, R., Minondo, A., Navarro, M., 2012. Related variety and regional growth in Spain. Papers in Regional Science 91.

Boschma, R. A., Wenting, R., 2007. The spatial evolution of the British automobile industry: Does location matter?. Industrial and Corporate Change 16(2), 213-238.

Boschma, R., Weterings, A., 2005. The effect of regional differences on the performance of software firms in the Netherlands. J. Econ. Geogr. 5, 567-588.

Boyack, K.W., Klavans, R., 2010. Co-citation analysis, bibliographic coupling, and direct citation: which citation approach represents the research front most accurately?. Journal of the American Society for Information Science and Technology, 61(12), 2389-2404.

Boyack, K.W., Klavans, R., 2014. Creation of a highly detailed, dynamic, global model and map of science. Journal of the Association for Information Science and Technology 65(4), 670-685.

Bresnahan, T., Gambardella, A., Saxenian, A., 2001. “Old Economy” Inputs for "New Economy" Outcomes: Cluster Formation in the New Silicon Valleys. Industrial and Corporate Change 10(4), 835-860.

Buenstorf, G., Klepper, S., 2009. Heritage and Agglomeration: The Akron Tyre Cluster Revisited. The Economic Journal 119(537), 705-733.

Cribier F., 1966. Industrial Districts of East-End of London. Annales De Geographie 75, 208-209.

Camison, C., 2004. Shared, competitive, and comparative advantages: a competencebased view of industrial-district competitiveness. Environment and Planning A 36, 2227-2256.

Camison, C., Villar-Lopez, A., 2012. On How Firms Located in an Industrial District Profit from Knowledge Spillovers: Adoption of an Organic Structure and Innovation Capabilities. British Journal of Management 23, 361-382.

Canina, L., Enz, C.A., Harrison, J.S., 2005. Agglomeration efects and strategic orientations: Evidence from the US lodging industry. Academy of Management Journal 48 (4), 565-581.

Chung, W., Kalnins, A., 2001. Agglomeration effects and performance: A test of the Texas lodging industry. Strategic Management Journal 22 (10), 969-988.

Cohen, W.M., Levinthal, D.A., 1990. Absorptive-Capacity - a New Perspective on Learning and Innovation. Adm. Sci. Q. 35, 128-152.

Costa, C., Baptista, R., 2012. Agglomeration vs. Organizational Reproduction: The Molds Cluster in Portugal. Papers in Evolutionary Economic Geography, 12/22, Utrecht University.

Cruz, S., Teixeira, A., 2010. The evolution of the cluster literature: shedding light on the regional studies. Regional Studies 44, 1263-1288. 
Decarolis, D. M., Deeds, D. L., 1999. The impact of stocks and flows of organizational knowledge on firm performance: an empirical investigation of the biotechnology industry. Strategic Management Journal 20 (10), 953-968.

Eisingerich, A.B., Bell, S.J., Tracey, P., 2010. How can clusters sustain performance? The role of network strength, network openness, and environmental uncertainty. Research Policy 39, 239-253.

Eriksson, R., 2011. Localized Spillovers and Knowledge Flows: How Does Proximity Influence the Performance of Plants?. Economic Geography 87, 127-152.

Eriksson, R., Lindgren, U., 2009. Localized mobility clusters: impacts of labour market externalities on firm performance. Journal of Economic Geography 9, 33-53.

Exposito-Langa, M., Molina-Morales, FX., Capo-Vicedo, J., 2011. New Product Development and Absorptive Capacity in Industrial Districts: A Multidimensional Approach. Regional Studies 45, 319-331.

Folta, T. B., Cooper, A. C., Baik, Y., 2006. Geographic cluster size and firm performance. Journal of Business Venturing 21 (2), 217-242.

Frenken, K., Boschma, R.A., 2007. A theoretical framework for evolutionary economic geography: industrial dynamics and urban growth as a branching process. Journal of Economic Geography 7, 635-649.

Frenken, K, van Oort, F.G., Verburg, T., 2007.Related variety, unrelated variety and regional economic growth. Regional Studies 41 (5), 685-697.

Garfield E., 1955. Citation indexes for science: a new dimension in documentation through association of ideas. Science 122, 108-111.

Gilbert, B.A., McDougall, P.P., Audretsch, D. B., 2008. Clusters, knowledge spillovers and new venture performance: An empirical examination. Journal of Business Venturing 23 (4), 405-422.

Giuliani, E., 2007. The selective nature of knowledge networks in clusters: evidence from the wine industry. Journal of Economic Geography 7, 139-168.

Giuliani, E., (a) 2013. Network dynamics in regional clusters: Evidence from Chile. Research Policy 42, 1406-1419.

Giuliani, E., (b) 2013. Clusters, networks and firms' product success: an empirical study. Management Decision 51, 1135-1160.

Giuliani, E., Bell, M., 2005. The micro-determinants of meso-level learning and innovation: evidence from a Chilean wine cluster. Research Policy 34, 47-68.

Glänzel, W., Thijs, B., 2012. Using 'core documents' for detecting and labeling new emerging topics. Scientometrics 91, 399-416.

Gluckler, J., 2007. Economic geography and the evolution of networks. Journal of Economic Geography 7, 619-634.

Gmür, M., 2003. Co-citation analysis and the search for invisible colleges: a methodological evaluation. Scientometrics 57(1), 27-57.

Gordon, I.R., McCann, P., 2000. Industrial clusters: Complexes, agglomeration and/or social networks?. Urban Studies 37, 513-532. 
Gregoire, D.A., Noel, M.X., Dery, R., Bechard, J.P., 2006. Is there conceptual convergence in entrepreneurship research? A co-citation analysis of Frontiers of Entrepreneurship Research, 1981-2004. Entrepreneurship Theory and Practice 30, 333-373.

Henning, M., Stam, E., Wenting, R., 2013. Path Dependence Research in Regional Economic Development: Cacophony or Knowledge Accumulation?. Regional Studies 47, 1348-1362.

Hervas-Oliver, J.L., Albors-Garrigos, J., 2009. The role of the firms internal and relational capabilities in clusters: when distance and embeddedness are not enough to explain innovation. Journal of Economic Geography 9, 263-283.

Hervas-Oliver, J.L., Albors-Garrigos, J., De-Miguel, B., Hidalgo, A., 2012. The role of a firm's absorptive capacity and the technology transfer process in clusters: How effective are technology centres in low-tech clusters?. Entrepreneurship and Regional Development 24, 523-559.

Huggins, R., (a) 2008. The Evolution of Knowledge Clusters Progress and Policy, Economic Development Quarterly 22, 277-289.

Huggins, R., (b) 2008. Universities and knowledge-based venturing: finance, management and networks in London. Entrepreneurship and Regional Development 20, 185-206.

Iammarino, S., McCann, P., 2006. The structure and evolution of industrial clusters: Transactions, technology and knowledge spillovers. Research Policy 35, 1018-1036.

Inkpen, A.C., Tsang, E.W.K., 2005. Social capital, networks, and knowledge transfer, Academy of Management Review 30, 146-165.

Jacobs, J., 1969. The Economy of Cities. New York: Vintaje.

Jarneving, B., 2007. Bibliographic coupling and its application to research-front and other core documents. Journal of Informetrics 1, 287-307.

Jarneving, B., 2005. A comparison of two bibliometric methods for mapping of the research front. Scientometrics 65, 245-263.

Kenney, M., 2000. Understanding Silicon Valley. Stanford University Press, Stanford,CA.

Kesidou, E., Snijders, C., 2012. External Knowledge and Innovation Performance in Clusters: Empirical Evidence from the Uruguay Software Cluster. Industry and Innovation 19, 437-457.

Kessler, M.M., 1963. Bibliographic coupling between scientific papers. American Documentation 14, 1-25.

Klepper, S., 2011. Nano-economics, spinoffs, and the wealth of regions. Small Business Economics 37(2), 141-154.

Klepper, S., 2007. Disagreements, spinoffs, and the evolution of Detroit as the capital of the US automobile industry. Management Science 53(4), 616-631.

Krugman, P., 1991. Increasing returns and economic geography. Journal of Political Economy 99, 483-499.

Kukalis, S., 2010. Agglomeration economies and firm performance: the case of industry clusters. Journal of Management 36, 453-481. 
Lazzeretti, L., Sedita, S. R., Caloffi, A., 2014. Founders and disseminators of cluster research. Journal of Economic Geography 14, 21-43.

Lorenzen, M., 2007. Social capital and localised learning: Proximity and place in technological and institutional dynamics. Urban Studies 44, 799-817.

MacKinnon, D., Cumbers, A., Pike, A., Birch, K., McMaster, R., 2009. Evolution in Economic Geography: Institutions, Political Economy, and Adaptation. Economic Geography 85, 129-150.

Malecki, E.J., 2012. Regional Social Capital: Why it Matters. Regional Studies 46, 10231039.

Malecki, E.J., (a) 2010. Global Knowledge and Creativity: New Challenges for Firms and Regions. Regional Studies 44, 1033-1052.

Malecki, E.J., (b) 2010. Everywhere? the geography of knowledge*. Journal of Regional Science 50, 493-513.

Malmberg, A., Maskell, P., 2002. The elusive concept of localization economies: towards a knowledge-based theory of spatial clustering. Environment and Planning A 34, 429-449.

Markusen, A., 1996. Sticky places in slippery space: A typology of industrial districts. Economic Geography 72, 293-313.

Markusen, J.R., 1985. Multinational Excursions - Kindleberger,cp. J. Int. Econ. 19, 192194.

Martin, R., 2010. Roepke Lecture in Economic Geography-Rethinking Regional Path Dependence: Beyond Lock-in to Evolution. Economic Geography 86, 1-27.

Martin, R., Sunley, P., 2006. Path dependence and regional economic evolution. Journal of Economic Geography 6, 395-437.

Martinez-Fernandez, M.T., Capo-Vicedo, J., Vallet-Bellmunt, T., 2012. The Present State of Research into Industrial Clusters and Districts. Content Analysis of Material Published in 1997-2006. European Planning Studies 20, 281-304.

Marshall, A., 1920. Principles of Economics. revised edn. London: Macmillan, reprinted by Prometheus Books, 1st edn., 1890.

Maskell, P., Bathelt, H., Malmberg, A., 2006. Building global knowledge pipelines: The role of temporary clusters. European Planning Studies 14, 997-1013.

Maskell, P., Malmberg, A., 2007. Myopia, knowledge development and cluster evolution. Journal of Economic Geography 7, 603-618.

Maskell, P., Malmberg, A., 1999. The competitiveness of firms and regions 'Ubiquitification' and the importance of localized learning. European Urban and Regional Studies 6, 9-25.

McCann, B. T., Folta, T. B., 2011. Performance differentials within geographic clusters. Journal of Business Venturing 26 (1), 104-123.

McEvily, B., Marcus, A., 2005. Embedded ties and the acquisition of competitive capabilities. Strategic Management Journal 26 (11), 1033-1055.

McEvily, B., Zaheer, A., 1999. Bridging ties: A source of firm heterogeneity in competitive capabilities. Strategic Management Journal 20 (12), 1133-1156. 
Menzel, M.P., Fornahl, D., 2010. Cluster life cycles-dimensions and rationales of cluster evolution. Industrial and Corporate Change 19, 205-238.

Molina-Morales, F.X., Martinez-Fernandez, M.T., 2003. The impact of industrial district affiliation on firm value creation. European Planning Studies 11, 155-170.

Morrison, A., 2008. Gatekeepers of knowledge within industrial districts: Who they are, how they interact. Regional Studies 42, 817-835.

Morrison, A., Rabellotti, R., Zirulia, L., 2013. When do Global Pipelines Enhance the Diffusion of Knowledge in Clusters?. Economic Geography 89, 77-96.

Nazarov, Y., 1962. The Problem of Organizing a Food-Supply Base for the Yeniseysk Industrial District. Soviet Geography Review and Translation 3, 45-55.

Neffke, F,Henning, M., Boschma, R., 2011. How do Regions Diversify over Time? Industry Relatedness and the Development of New Growth Paths in Regions. Economic Geography 87, 237-265.

Nelson, R.R., Winter, S.G., 1982. The Schumpeterian Trade off Revisited. Am. Econ. Rev. 72, 114-132.

Owen-Smith, J., Powell, W.W., 2004. Knowledge networks as channels and conduits: the effects of spillovers in the Boston biotechnology locale. Organization Science

Pe'er, A., Keil, T., 2013. Are all startups affected similarly by clusters? Agglomeration, competition, firm heterogeneity, and survival. Journal of Business Venturing 28 (3), 354-372.

Persson, O., 1994. The intelectual base and research fronts of JASIS 1986-1990. Journal of the American Society for Information Science 45(1), 31-38.

Piore, M. J., Sabel, C. F., 1984. The Second Industrial Divide. New York:Free Press.

Porter, M. E., 1998. Clusters and the new economics of competition. Harvard Business Review 76 (6), 77-90.

Porter, M. E., 1990. The Competitive Advantage of Nations. New York: Free Press.

Potter, A. and Watts, H. D., 2010. Evolutionary Agglomeration Theory: Increasing Returns, Diminishing Returns, and the Industry Life Cycle. Journal of Economic Geography 11 (3), 417-55.

Rigby, D. L., Brown, W. M., 2013.Who benefits from agglomeration?. Regional Studies DOI: $10.1080 / 00343404.2012 .753141: 1-16$.

Romanelli, E., Khessina, O., 2005. Regional industrial identity: Cluster configurations and economic development. Organization Science 16, 344-358.

Romer, P., 1986. Increasing returns and long-run growth. Journal of Political Economy 94, 1002-1037.

Rosenkopf, L., Almeida, P., 2003. Overcoming local search through alliances and mobility. Management Science 49, 751-766.

Rosenkopf, L., Padula, G., 2008. Investigating the Microstructure of Network Evolution: Alliance Formation in the Mobile Communications Industry. Organization Science 19, 669-687.

Saxenian, A., 1994. Regional advantage: Culture and Competition in Silicon Valley and Route 128. Harvard University Press: Cambridge, MA. 
Saxenian, A., 1990. Regional networks and the resurgence of Silicon Valley. California Management Review 33 (1), 89-113.

Shaver, J. M., Flyer, F., 2000. Agglomeration economies, firm heterogeneity, and foreign direct investment in the United States. Strategic Management Journal 21 (12), 11751194.

Shibata, N., Kajikawa, Y., Takeda, Y., Matsushima, K., 2008. Comparative study on methods of detecting research fronts using different types of citation. Journal of the American Society for Information Science and Technology 60(3), 571-580.

Small, H., 2009. Critical thresholds for co-citation clusters and emergence of the giant component. Journal of Informetrics 3(4), 332-340.

Sorenson, O., Audia, P. G., 2000. The Social Structure of Entrepreneurial Activity: Geographic Concentration of Footwear Production in the United States, 1940 19891. American Journal of Sociology 106 (2), 424-462.

Stuart, T., Sorenson, O., 2003. The geography of opportunity: spatial heterogeneity in founding rates and the performance of biotechnology firms. Research policy 32 (2), 229-253.

Ter Wal, A., Boschma, R., 2011. Co-evolution of Firms, Industries and Networks in Space. $\quad$ Regional Studies 45, 919-933.

Vogel, R., Güttel, W. H., 2013. The dynamic capability view in strategic management: a bibliometric review. International Journal of Management Reviews 15(4), 426-446.

Wagner, C., 1957. Planned Industrial Districts. Journal of Geography 56, 129-132.

Weiss, S., Kaiser, E., 1968. Quantitative Evaluation of Major Factors Influencing Urban Land Development in a Regional Cluster. Ekistics 25, 338-342.

Wenting, R., 2008. Spinoff dynamics and the spatial formation of the fashion design industry, 1858-2005. Journal of Economic Geography 8, 593-614.

Whittington, K.B., Owen-Smith, J., Powell, W.W., 2009. Networks, Propinquity, and Innovation in Knowledge-intensive Industries. Administrative Science Quarterly 54, 90-122.

Yang, E., Ding, Y., 2012. Scholarly network similarities: how bibliographic coupling networks, citation Networks, cocitation networks, topical networks, coauthorship networks, and coword networks relate to each other. Journal of the American Society for Information Science and Technology 63(7), 1313-1326.

\section{References analyzed}

Angel, D., 2002. Inter-firm collaboration and technology development partnerships within US manufacturing industries. Reg. Stud. 36, 333-344.

Arikan, A.T., 2009. Interfirm Knowledge Exchanges and the Knowledge Creation Capability of Clusters. Academy of Management Review 34, 658-676.

Arikan, A.T., Schilling, M.A., 2011. Structure and Governance in Industrial Districts: Implications for Competitive Advantage. Journal of Management Studies 48, 772803. 
Audia, P.G., Rider, C.I., 2010. Close, but not the same: Locally headquartered organizations and agglomeration economies in a declining industry. Research Policy 39, 360-374.

Baldwin, J.R., Beckstead, D., Brown, W.M., Rigby, D.L., 2008. Agglomeration and the geography of localization economies in Canada. Reg. Stud. 42, 117-132.

Bathelt, H., (b) 2005. Cluster relations in the media industry: Exploring the 'distanced neighbour' paradox in Leipzig. Reg. Stud. 39, 105-127.

Bathelt, H., (a) 2005. Geographies of production: growth regimes in spatial perspective (II) - knowledge creation and growth in clusters. Progress in Human Geography 29, 204-216.

Bathelt, H., 2002. The re-emergence of a media industry cluster in Leipzig. European Planning Studies 10, 583-611.

Bathelt, H., 2001. Regional competence and economic recovery: divergent growth paths in Boston's high technology economy. Entrepreneurship and Regional Development 13, 287-314.

Bathelt, H., Boggs, J., 2003. Toward a reconceptualization of regional development paths: Is Leipzig's media cluster a continuation of or a rupture with the past? Economic Geography 79, 265-293.

Bathelt, H., Gluckler, J., 2005. Resources in economic geography: from substantive concepts towards a relational perspective. Environ. Plann. A 37, 1545-1563.

Bathelt, H., Malmberg, A., Maskell, P., 2004. Clusters and knowledge: local buzz, global pipelines and the process of knowledge creation. Prog. Hum. Geogr. 28, 31-56.

Bathelt, H., Graef, A., 2008. Internal and external dynamics of the Munich film and TV industry cluster, and limitations to future growth. Environ. Plann. A 40, 1944-1965.

Bathelt, H., Schuldt, N., 2010. International Trade Fairs and Global Buzz, Part I: Ecology of Global Buzz. European Planning Studies 18, 1957-1974.

Bathelt, H., Schuldt, N., 2008. Between luminaires and meat grinders: International trade fairs as temporary clusters. Reg. Stud. 42, 853-868.

Bathelt, H., Turi, P., 2011. Local, global and virtual buzz: The importance of face-to-face contact in economic interaction and possibilities to go beyond. Geoforum 42, 520 529.

Beaudry, C., Schiffauerova, A., 2009. Who's right, Marshall or Jacobs? The localization versus urbanization debate. Res. Policy 38, 318-337.

Belussi, F., Sammarra, A., Sedita, SR., 2008. Managing long distance and localized learning in the Emilia Romagna life science cluster. European Planning Studies 16, 665-692.

Belussi, F., Sedita, S.R., 2012. Industrial Districts as Open Learning Systems: Combining Emergent and Deliberate Knowledge Structures. Reg. Stud. 46, 165-184.

Belussi, F., Sedita, S.R., 2009. Life Cycle vs. Multiple Path Dependency in Industrial Districts. European Planning Studies 17, 505-528.

Boschma, R., Weterings, A., 2005. The effect of regional differences on the performance of software firms in the Netherlands. J. Econ. Geogr. 5, 567-588. 
Boschma, R.A., Frenken, K., 2006. Why is economic geography not an evolutionary science? Towards an evolutionary economic geography. J. Econ. Geogr. 6, 273-302.

Boschma, R.A., Wenting, R., 2007. The spatial evolution of the British automobile industry: Does location matter? industrial and corporate change 16, 213-238.

Boschma, R., Eriksson, R., Lindgren, U., 2009. How does labour mobility affect the performance of plants The importance of relatedness and geographical proximity. Journal of Economic Geography 9, 169-190.

Boschma, R., Frenken, K., 2011. The emerging empirics of evolutionary economic geography. Journal of Economic Geography 11, 295-307.

Boschma, R., Frenken, K., 2009. Some Notes on Institutions in Evolutionary Economic Geography. Economic Geography 85, 151-158.

Britton, J., 2004. High technology localization and extra-regional networks. Entrepreneurship and Regional Development 16, 369-390.

Britton, J., 2003. Network structure of an industrial cluster: electronics in Toronto. Environment and Planning A 35, 983-1006.

Buenstorf, G., Fornahl, D., 2009. B2C-bubble to cluster: the dot-com boom, spin-off entrepreneurship, and regional agglomeration. Journal of Evolutionary Economics 19, 349-378.

Buenstorf, G., Guenther, C., 2011. No place like home? Relocation, capabilities, and firm survival in the German machine tool industry after World War II. Ind. Corp. Change 20, 1-28.

Buenstorf, G., Klepper, S., 2010. Why does entry cluster geographically? Evidence from the US tire industry. J. Urban Econ. 68, 103-114.

Camison, C., 2004. Shared, competitive, and comparative advantages: a competencebased view of industrial-district competitiveness. Environ. Plann. A 36, 2227-2256.

Camison, C., Fores, B., 2011. Knowledge creation and absorptive capacity: The effect of intra-district shared competences. Scandinavian Journal of Management 27, 66-86.

Camison, C., Villar-Lopez, A., 2012. On How Firms Located in an Industrial District Profit from Knowledge Spillovers: Adoption of an Organic Structure and Innovation Capabilities. British Journal of Management 23, 361-382.

Camuffo, A., Grandinetti, R., 2011. Italian industrial districts as cognitive systems: Are they still reproducible? Entrepreneurship and Regional Development 23, 815-852.

Canina, L., Enz, C., Harrison, J., 2005. Agglomeration efects and strategic orientations: Evidence from the US lodging industry. Academy of Management Journal 48, 565581.

Cantner, U., Conti, E., Meder, A., 2010. Networks and Innovation: The Role of Social Assets in Explaining Firms' Innovative Capacity. European Planning Studies 18, 1937-1956.

Casanueva, C., Castro, I., Galan, J.L., 2013. Informational networks and innovation in mature industrial clusters. Journal of Business Research 66, 603-613.

Chiu, Y.H., Lee, T., 2012. Structural embeddedness and innovation performance: Capitalizing on social brokerage in high-tech clusters. Innovation-Management Policy \& Practice 14, 337-348. 
Christiansen, E.A.N., Jakobsen, S., 2012. Embedded and Disembedded Practice in the Firm-Place Nexus: a Study of Two World-Leading Manufacturers of Ski Equipment in the Lillehammer Ski Cluster. Geografiska Annaler Series B-Human Geography 94B, 177-194.

Coe, N.M., 2011. Geographies of production I: An evolutionary revolution? Prog. Hum. Geogr. 35, 81-91.

Coombs, J.E., Deeds, D.L., Ireland, R.D., 2009. Placing the Choice between Exploration and Exploitation in Context: a Study of Geography and New Product Development. Strateg. Entrep. J. 3, 261-279.

Cruz, S.C.S., Teixeira, A.A.C., 2010. The Evolution of the Cluster Literature: Shedding Light on the Regional Studies-Regional Science Debate. Reg. Stud. 44, 1263-1288.

Czarnitzki, D., Hottenrott, H., 2009. Are Local Milieus the Key to Innovation Performance? J. Reg. Sci. 49, 81-112.

De Figueiredo, R.J.P., Meyer-Doyle, P., Rawley, E., 2013. Inherited agglomeration effects in hedge fund spawns. Strategic Manage. J. 34, 843-862.

De Vaan, M., Boschma, R., Frenken, K., 2013. Clustering and firm performance in project-based industries: the case of the global video game industry, 1972-2007. Journal of Economic Geography 13, 965-991.

Delerue, H., Lejeune, A., 2012. Internationalization of biotechnology start-ups: Geographic location and mimetic behaviour. International Small Business Journal 30, 388-405.

Depner, H., Bathelt, H., 2005. Exporting the German model: The establishment of a new automobile industry cluster in Shanghai. Economic Geography 81, 53-81.

D'Este, P., Guy, F., Iammarino, S., 2013. Shaping the formation of university-industry research collaborations: what type of proximity does really matter? Journal of Economic Geography 13, 537-558.

Drucker, J., 2011. Regional Industrial Structure Concentration in the United States: Trends and Implications. Econ. Geogr. 87, 421-452.

Drucker, J., Feser, E., 2012. Regional industrial structure and agglomeration economies: An analysis of productivity in three manufacturing industries. Reg. Sci. Urban Econ. 42, 1-14.

Eisingerich, A.B., Bell, S.J., Tracey, P., 2010. How can clusters sustain performance? The role of network strength, network openness, and environmental uncertainty. Research Policy 39, 239-253.

Elola, A., Valdaliso, J., Lopez, S.M., Jose Aranguren, M., 2012. Cluster Life Cycles, Path Dependency and Regional Economic Development: Insights from a Meta-Study on Basque Clusters. European Planning Studies 20, 257-279.

Engelstoft, S., Jensen-Butler, C., Smith, I., Winther, L., 2006. Industrial clusters in Denmark: Theory and empirical evidence. Papers in Regional Science 85, 73-97.

Eriksson, R.H., 2011. Localized Spillovers and Knowledge Flows: How Does Proximity Influence the Performance of Plants? Economic Geography 87, 127-152.

Eriksson, R., Lindgren, U., 2009. Localized mobility clusters: impacts of labour market externalities on firm performance. Journal of Economic Geography 9, 33-53. 
Eriksson, R., Lindgren, U., Malmberg, G., 2008. Agglomeration mobility: effects of localisation, urbanisation, and scale on job changes. Environ. Plann. A 40, 24192434.

Essletzbichler, J., Rigby, D.L., 2007. Exploring evolutionary economic geographies. J. Econ. Geogr. 7, 549-571.

Exposito-Langa, M., Molina-Morales, F.X., Capo-Vicedo, J., 2011. New Product Development and Absorptive Capacity in Industrial Districts: A Multidimensional Approach. Reg. Stud. 45, 319-331.

Exposito-Langa, M., Xavier Molina-Morales, F., 2010. How Relational Dimensions Affect Knowledge Redundancy in Industrial Clusters. European Planning Studies 18, 1975-1992.

Flyer, F., Shaver, J., 2003. Location choices under agglomeration externalities and strategic interaction. Geography and Strategy 20, 193-213.

Folta, T., Cooper, A., Baik, Y., 2006. Geographic cluster size and firm performance. Journal of Business Venturing 21, 217-242.

Frenken, K., Boschma, R.A., 2007. A theoretical framework for evolutionary economic geography: industrial dynamics and urban growth as a branching process. J. Econ. Geogr. 7, 635-649.

Fuellhart, K., 1999. Localization and the use of information sources: The case of the carpet industry. Eur. Urban Reg. Stud. 6, 39-58.

Fuellhart, K., Glasmeier, A., 2003. Acquisition, assessment and use of business information by small- and medium-sized businesses: a demand perspective. Entrep. Reg. Dev. 15, 229-252.

Gilbert, B.A., McDougall, P.P., Audretsch, D.B., 2008. Clusters, knowledge spillovers and new venture performance: An empirical examination. Journal of Business Venturing 23, 405-422.

Giuliani, E., Bell, M., 2005. The micro-determinants of meso-level learning and innovation: evidence from a Chilean wine cluster. Research Policy 34, 47-68.

Giuliani, E., 2013. Clusters, networks and firms' product success: an empirical study. Management Decision 51, 1135-1160.

Giuliani, E., 2013. Network dynamics in regional clusters: Evidence from Chile. Research Policy 42, 1406-1419.

Giuliani, E., 2011. Role of Technological Gatekeepers in the Growth of Industrial Clusters: Evidence from Chile. Reg. Stud. 45, 1329-1348.

Giuliani, E., 2007. The selective nature of knowledge networks in clusters: evidence from the wine industry. Journal of Economic Geography 7, 139-168.

Giuliani, E., 2005. Cluster absorptive capacity - Why do some clusters forge ahead and others lag behind?. European Urban and Regional Studies 12, 269-288.

Glueckler, J., 2007. Economic geography and the evolution of networks. J. Econ. Geogr. 7, 619-634.

Gnyawali, D.R., Srivastava, M.K., 2013. Complementary effects of clusters and networks on firm innovation: A conceptual model. J. Eng. Technol. Manage. 30, 120. 
Gordon, I., McCann, P., 2005. Innovation, agglomeration, and regional development. Journal of Economic Geography 5, 523-543.

Gordon, I., McCann, P., 2000. Industrial clusters: Complexes, agglomeration and/or social networks? Urban Stud. 37, 513-532.

Gulati, R., Sytch, M., Tatarynowicz, A., 2012. The Rise and Fall of Small Worlds: Exploring the Dynamics of Social Structure. Organization Science 23, 449-471.

Hassink, R., 2010. Regional resilience: a promising concept to explain differences in regional economic adaptability? Cambridge Journal of Regions Economy and Society 3, 45-58.

He, Z., Wong, P., 2012. Reaching Out and Reaching Within: A Study of the Relationship between Innovation Collaboration and Innovation Performance. Industry and Innovation 19, 539-561.

Heebels, B., Boschma, R., 2011. Performing in Dutch book publishing 1880-2008: the importance of entrepreneurial experience and the Amsterdam cluster. Journal of Economic Geography 11, 1007-1029.

Henning, M., Stam, E., Wenting, R., 2013. Path Dependence Research in Regional Economic Development: Cacophony or Knowledge Accumulation? Reg. Stud. 47, 1348-1362.

Hervas-Oliver, J., Albors-Garrigos, J., 2009. The role of the firms internal and relational capabilities in clusters: when distance and embeddedness are not enough to explain innovation. Journal of Economic Geography 9, 263-283.

Hervas-Oliver, J., Albors-Garrigos, J., 2008. Local knowledge domains and the role of MNE affiliates in bridging and complementing a cluster's knowledge. Entrepreneurship and Regional Development 20, 581-598.

Hervas-Oliver, J.L., Albors-Garrigos, J., 2007. Do clusters capabilities matter? An empirical application of the resource-based view in clusters. Entrepreneurship and Regional Development 19, 113-136.

Hervas-Oliver, J.L., Albors-Garrigos, J.A., Dalmau-Porta, J.I., 2008. External ties and the reduction of knowledge asymmetries among clusters within global value chains: The case of the ceramic tile district of Castellon. European Planning Studies 16, 507-520.

Hervas-Oliver, J., Albors-Garrigos, J., de-Miguel, B., Hidalgo, A., 2012. The role of a firm's absorptive capacity and the technology transfer process in clusters: How effective are technology centres in low-tech clusters? Entrepreneurship and Regional Development 24, 523-559.

Hervas-Oliver, J., Albors-Garrigos, J., Hidalgo, A., 2011. Global value chain reconfiguration through external linkages and the development of newcomers: a global story of clusters and innovation. Int. J. Technol. Manage. 55, 82-109.

Hsieh, P., Lee, C., Ho, J.C., 2012. Strategy and process of value creation and appropriation in service clusters. Technovation 32, 430-439.

Huggins, R., 2011. The Growth of Knowledge-Intensive Business Services: Innovation, Markets and Networks. European Planning Studies 19, 1459-1480.

Huggins, R., 2008. The Evolution of Knowledge Clusters Progress and Policy. Economic Development Quarterly 22, 277-289. 
Huggins, R., 2008. Universities and knowledge-based venturing: finance, management and networks in London. Entrepreneurship and Regional Development 20, 185-206.

Huggins, R., Johnston, A., 2012. Knowledge alliances and innovation performance: an empirical perspective on the role of network resources. Int. J. Technol. Manage. 57, 245-265.

Huggins, R., Johnston, A., 2010. Knowledge flow and inter-firm networks: The influence of network resources, spatial proximity and firm size. Entrepreneurship and Regional Development 22, 457-484.

Huggins, R., Johnston, A., Thompson, P., 2012. Network Capital, Social Capital and Knowledge Flow: How the Nature of Inter-organizational Networks Impacts on Innovation. Industry and Innovation 19, 203-232.

Iammarino, S., McCann, P., 2006. The structure and evolution of industrial clusters: Transactions, technology and knowledge spillovers. Res. Policy 35, 1018-1036.

Inkpen, A.C., Tsang, E.W.K., 2005. Social capital, networks, and knowledge transfer, Academy of Management Review 30, 146-165.

Jaffee, J., 2003. Law firm office location and firm survival in Silicon Valley, 1969 to 1998. Geography and Strategy 20, 341-376.

Kajikawa, Y., Mori, J., Sakata, I., 2012. Identifying and bridging networks in regional clusters. Technological Forecasting and Social Change 79, 252-262.

Kajikawa, Y., Takeda, Y., Sakata, I., Matsushima, K., 2010. Multiscale analysis of interfirm networks in regional clusters. Technovation 30, 168-180.

Kesidou, E., Snijders, C., 2012. External Knowledge and Innovation Performance in Clusters: Empirical Evidence from the Uruguay Software Cluster. Industry and Innovation 19, 437-457.

Klepper, S., 2011. Nano-economics, spinoffs, and the wealth of regions. Small Business Economics 37, 141-154.

Klepper, S., 2010. The origin and growth of industry clusters: The making of Silicon Valley and Detroit. J. Urban Econ. 67, 15-32.

Klepper, S., 2009. Spinoffs: A review and synthesis. Eur. Manag. Rev. 6, 159-171.

Klepper, S., 2007. Disagreements, spinoffs, and the evolution of Detroit as the capital of the US automobile industry. Management Science 53, 616-631.

Kloosterman, R.C., 2008. Walls and bridges: knowledge spillover between 'superdutch' architectural firms. Journal of Economic Geography 8, 545-563.

Lee, C., 2009. How does a cluster relocate across the border? The case of information technology cluster in the Taiwan-Suzhou region. Technological Forecasting and Social Change 76, 371-381.

Li, J., Geng, S., 2012. Industrial clusters, shared resources and firm performance. Entrepreneurship and Regional Development 24, 357-381.

Liargovas, P., Daskalopoulou, I., 2011. Capital allocation in the Greek regions. J. Policy Model. 33, 866-888.

Lorenzen, M., 2007. Social capital and localised learning: Proximity and place in technological and institutional dynamics. Urban Stud. 44, 799-817. 
MacKinnon, D., Cumbers, A., Pike, A., Birch, K., McMaster, R., 2009. Evolution in Economic Geography: Institutions, Political Economy, and Adaptation. Econ. Geogr. 85, 129-150.

Malecki, E.J., 2012. Regional Social Capital: Why it Matters. Reg. Stud. 46, 1023-1039.

Malecki, E.J., 2010. Global Knowledge and Creativity: New Challenges for Firms and Regions. Reg. Stud. 44, 1033-1052.

Malecki, E.J., 2010. Everywhere? the geography of knowledge*. Journal of Regional Science 50, 493-513.

Malmberg, A., Malmberg, B., Lundequist, P., 2000. Agglomeration and firm performance: economies of scale, localisation, and urbanisation among Swedish export firms. Environ. Plann. A 32, 305-321.

Malmberg, A., Maskell, P., 2002. The elusive concept of localization economies: towards a knowledge-based theory of spatial clustering. Environ. Plann. A 34, 429-449.

Martin, R., 2010. Roepke Lecture in Economic Geography-Rethinking Regional Path Dependence: Beyond Lock-in to Evolution. Economic Geography 86, 1-27.

Martin, R., Sunley, P., 2006. Path dependence and regional economic evolution. J. Econ. Geogr. 6, 395-437.

Martinez-Fernandez, M.T., Capo-Vicedo, J., Vallet-Bellmunt, T., 2012. The Present State of Research into Industrial Clusters and Districts. Content Analysis of Material Published in 1997-2006. European Planning Studies 20, 281-304.

Maskell, P., Lorenzen, M., 2004. The cluster as market organization. Urban Studies 41, 991-1009.

Maskell, P., Malmberg, A., 1999. Localised learning and industrial competitiveness. Cambr. J. Econ. 23, 167-185.

Maskell, P., Bathelt, H., Malmberg, A., 2006. Building global knowledge pipelines: The role of temporary clusters. European Planning Studies 14, 997-1013.

Maskell, P., Malmberg, A., 2007. Myopia, knowledge development and cluster evolution. Journal of Economic Geography 7, 603-618.

Mayer, H., 2013. Entrepreneurship in a Hub-and-Spoke Industrial District: Firm Survey Evidence from Seattle's Technology Industry. Reg. Stud. 47, 1715-1733.

McCann, B.T., Folta, T.B., 2011. Performance differentials within geographic clusters. Journal of Business Venturing 26, 104-123.

McCann, B.T., Vroom, G., 2010. Pricing Response to Entry and Agglomeration Effects. Strategic Manage. J. 31, 284-305.

McCann, P., 2007. Observational equivalence? Regional studies and regional science. Regional Studies 41, 1209-1221.

McCann, P., Mudambi, R., 2005. Analytical differences in the economics of geography: the case of the multinational firm. Environment and Planning A 37, 1857-1876.

McCann, P., Sheppard, S., 2003. The rise, fall and rise again of industrial location theory. Reg. Stud. 37, 649-663.

Menzel, M., Fornahl, D., 2010. Cluster life cycles-dimensions and rationales of cluster evolution. Industrial and Corporate Change 19, 205-238. 
Molina-Morales, F.X., Exposito-Langa, M., 2012. The impact of cluster connectedness on firm innovation: R\&D effort and outcomes in the textile industry. Entrepreneurship and Regional Development 24, 685-704.

Molina-Morales, F.X., Martines-Fernandez, M.T., 2009. Does homogeneity exist within industrial districts? A social capital-based approach. Papers in Regional Science 88, 209-229.

Molina-Morales, F.X., Martinez-Fernandez, M.T., 2010. Social Networks: Effects of Social Capital on Firm Innovation. J. Small Bus. Manage. 48, 258-279.

Molina-Morales, F.X, Martinez-Fernandez, M.T., 2009. Too Much Love in the Neighborhood can Hurt: how an Excess of Intensity and Trust in Relationships may Produce Negative Effects on Firms. Strategic Manage. J. 30, 1013-1023.

Molina-Morales, F.X., Martinez-Fernandez, M.T., 2008. Shared resources in industrial districts: Information, know-how and institutions in the Spanish tile industry. International Regional Science Review 31, 35-61.

Molina-Morales, F.X., Martinez-Fernandez, M.T., 2006. Industrial districts: something more than a neighbourhood. Entrepreneurship and Regional Development 18, 503524.

Molina-Morales, F.X., Martinez-Fernandez, M.T., Coll-Serrano, V., 2012. Efficiency and Innovation in Sub-Networks of Companies. a Study of the Spanish Ceramics District. Innovar-Revista De Ciencias Administrativas Y Sociales 22, 111-127.

Molina-Morales, F.X., Martinez-Fernandez, M.T., Torlo, V.J., 2011. The Dark Side of Trust: The Benefits, Costs and Optimal Levels of Trust for Innovation Performance. Long Range Plann. 44, 118-133.

Molina-Morales, F.X., Mas-Verdu, F., 2008. Intended ties with local institutions as factors in innovation: An application to Spanish manufacturing firms. European Planning Studies 16, 811-827.

Molina-Morales, F., 2002. Industrial districts and innovation: the case of the Spanish ceramic tiles industry. Entrepreneurship and Regional Development 14, 317-335.

Molina-Morales, F., Lopez-Navarro, M., Guia-Julve, J., 2002. The role of local institutions as intermediary agents in the industrial district. European Urban and Regional Studies 9, 315-329.

Molina-Morales, F., Martinez-Fernandez, M., 2004. Factors that identify industrial districts: an application in Spanish manufacturing firms. Environ. Plann. A 36, 111126.

Molina-Morales, F., Martinez-Fernandez, M., 2004. How much difference is there between industrial district firms? A net value creation approach. Research Policy 33, 473-486.

Molina-Morales, F., Martinez-Fernandez, M., 2003. The impact of industrial district affiliation on firm value creation. European Planning Studies 11, 155-170.

Moreno, R., Miguelez, E., 2012. A relational approach to the geography of innovation: a typology of regions. Journal of Economic Surveys 26, 492-516.

Morrison, A., 2008. Gatekeepers of knowledge within industrial districts: Who they are, how they interact. Reg. Stud. 42, 817-835. 
Morrison, A., Rabellotti, R., 2009. Knowledge and Information Networks in an Italian Wine Cluster. European Planning Studies 17, 983-1006.

Morrison, A., Rabellotti, R., Zirulia, L., 2013. When Do Global Pipelines Enhance the Diffusion of Knowledge in Clusters? Economic Geography 89, 77-96.

Murphy, J.T., 2006. Building trust in economic space. Prog. Hum. Geogr. 30, 427-450.

Murphy, J., 2002. Networks, trust, and innovation in Tanzania's manufacturing sector. World Dev. 30, 591-619.

Neffke, F., Henning, M., Boschma, R., 2011. How Do Regions Diversify over Time? Industry Relatedness and the Development of New Growth Paths in Regions. Economic Geography 87, 237-265.

Payne, G.T., Kennedy, K.H., Davis, J.L., 2009. Competitive Dynamics among Service SMEs. J. Small Bus. Manage. 47, 421-442.

Pe'er, A., Keil, T., 2013. Are all startups affected similarly by clusters? Agglomeration, competition, firm heterogeneity, and survival. Journal of Business Venturing 28, 354-372.

Petrou, A., Daskalopoulou, I., 2009. Innovation and Small Firms' Growth Prospects: Relational Proximity and Knowledge Dynamics in a Low-tech Industry. European Planning Studies 17, 1591-1604.

Pitelis, C., 2012. Clusters, entrepreneurial ecosystem co-creation, and appropriability: a conceptual framework. Industrial and Corporate Change 21, 1359-1388.

Potter, A., Watts, H.D., 2011. Evolutionary agglomeration theory: increasing returns, diminishing returns, and the industry life cycle. Journal of Economic Geography 11, 417-455.

Presutti, M., Boari, C., Majocchi, A., 2013. Inter-organizational geographical proximity and local start-ups' knowledge acquisition: a contingency approach. Entrepreneurship and Regional Development 25, 446-467.

Presutti, M., Boari, C., Majocchi, A., 2011. The Importance of Proximity for the StartUps' Knowledge Acquisition and Exploitation. J. Small Bus. Manage. 49, 361-389.

Quintana-Garcia, C., Benavides-Velasco, C., 2006. Searching for complementary technological knowledge and downstream competences: clustering and cooperation. Int. J. Technol. Manage. 35, 262-283.

Renski, H., 2011. External economies of localization, urbanization and industrial diversity and new firm survival. Pap. Reg. Sci. 90, 473-502.

Rosenkopf, L., Padula, G., 2008. Investigating the Microstructure of Network Evolution: Alliance Formation in the Mobile Communications Industry. Organization Science 19, 669-687.

Sammarra, A., Biggiero, L., 2008. Heterogeneity and specificity of inter-firm knowledge flows in innovation networks. Journal of Management Studies 45, 200-829.

Schuldt, N., Bathelt, H., 2011. International Trade Fairs and Global Buzz. Part II: Practices of Global Buzz. European Planning Studies 19, 1-22.

Schuldt, N., Bathelt, H., 2009. Reflexive time-space constructions and the role of global buzz at trade fairs. Zeitschrift Fur Wirtschaftsgeographie 53, 235-248. 
Shaver, J., Flyer, F., 2000. Agglomeration economies, firm heterogeneity, and foreign direct investment in the United States. Strategic Manage. J. 21, 1175-1193.

Strotmann, H., 2007. Entrepreneurial survival. Small Bus. Econ. Group 28, 87-104.

Stuart, T., Sorenson, O., 2003. The geography of opportunity: spatial heterogeneity in founding rates and the performance of biotechnology firms. Research Policy 32, 229-253.

Takeda, Y., Kajlkawa, Y., Sakata, I., Matsushima, K., 2008. An analysis of geographical agglomeration and modularized industrial networks in a regional cluster: A case study at Yamagata prefecture in Japan. Technovation 28, 531-539.

Ter Wal, A.L.J., Boschma, R., 2011. Co-evolution of Firms, Industries and Networks in Space. Reg. Stud. 45, 919-933.

Ter Wal, A.L.J., Boschma, R.A., 2009. Applying social network analysis in economic geography: framing some key analytic issues. Ann. Reg. Sci. 43, 739-756.

Valdaliso, J., Elola, A., Aranguren, M., Lopez, S., 2011. Social capital, internationalization and absorptive capacity: The electronics and ICT cluster of the Basque Country. Entrepreneurship and Regional Development 23, 707-733.

Van Hemert, P., Nijkamp, P., Masurel, E., 2013. From innovation to commercialization through networks and agglomerations: analysis of sources of innovation, innovation capabilities and performance of Dutch SMEs. Ann. Reg. Sci. 50, 425-452.

Wennberg, K., Lindqvist, G., 2010. The effect of clusters on the survival and performance of new firms. Small Business Economics 34, 221-241.

Whittington, K.B., Owen-Smith, J., Powell, W.W., 2009. Networks, Propinquity, and Innovation in Knowledge-intensive Industries. Adm. Sci. Q. 54, 90-122.

Wu, H., Chen, H., Lee, K., 2010. Unveiling the core technology structure for companies through patent information. Technological Forecasting and Social Change 77, 11671178. 


\section{Tables and figures}

Figure 1. Graphic representation of bibliometric methods

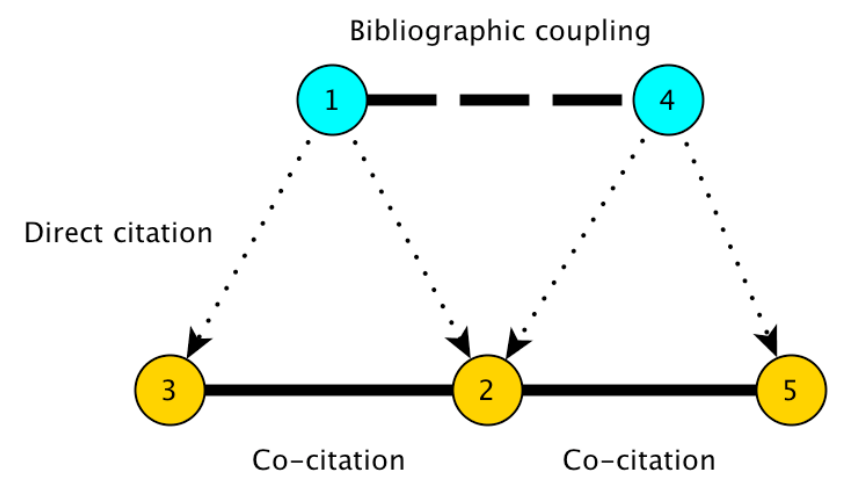

Figure 2. Example of bibliographic coupling

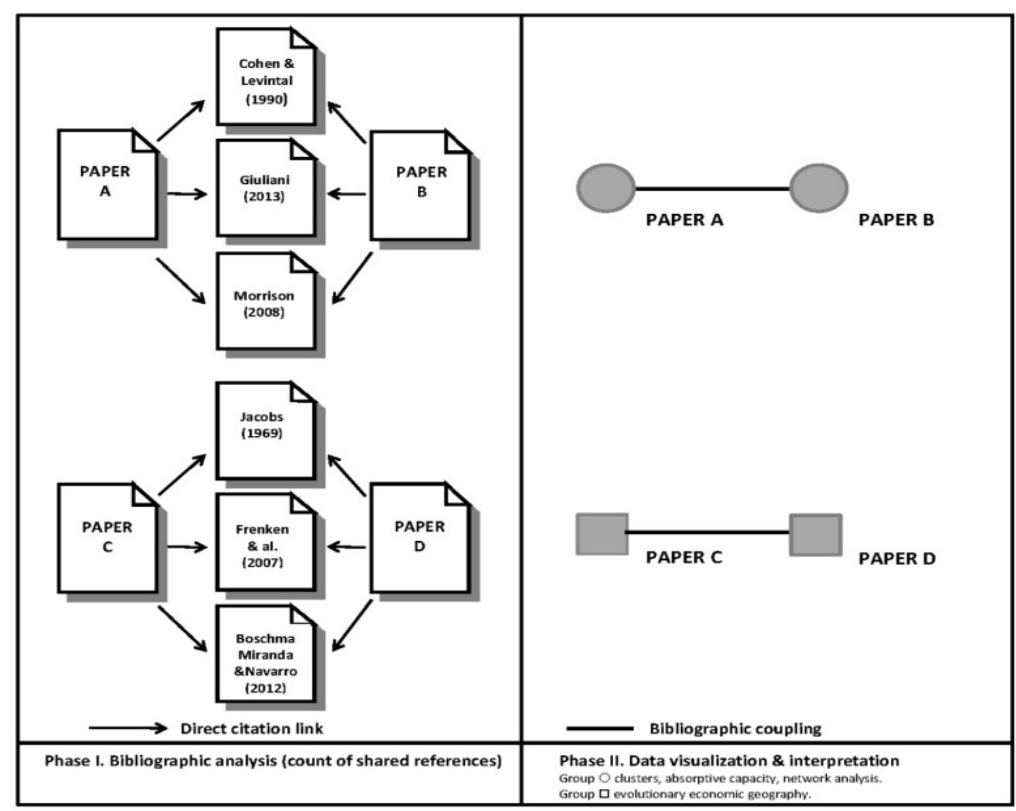

Source: own. This is only an example. Notice that the formation of a group requires a minimum number of shared references. 
Figure 3. Networks of bibliographic coupling (frequency counts, 1957-2013)

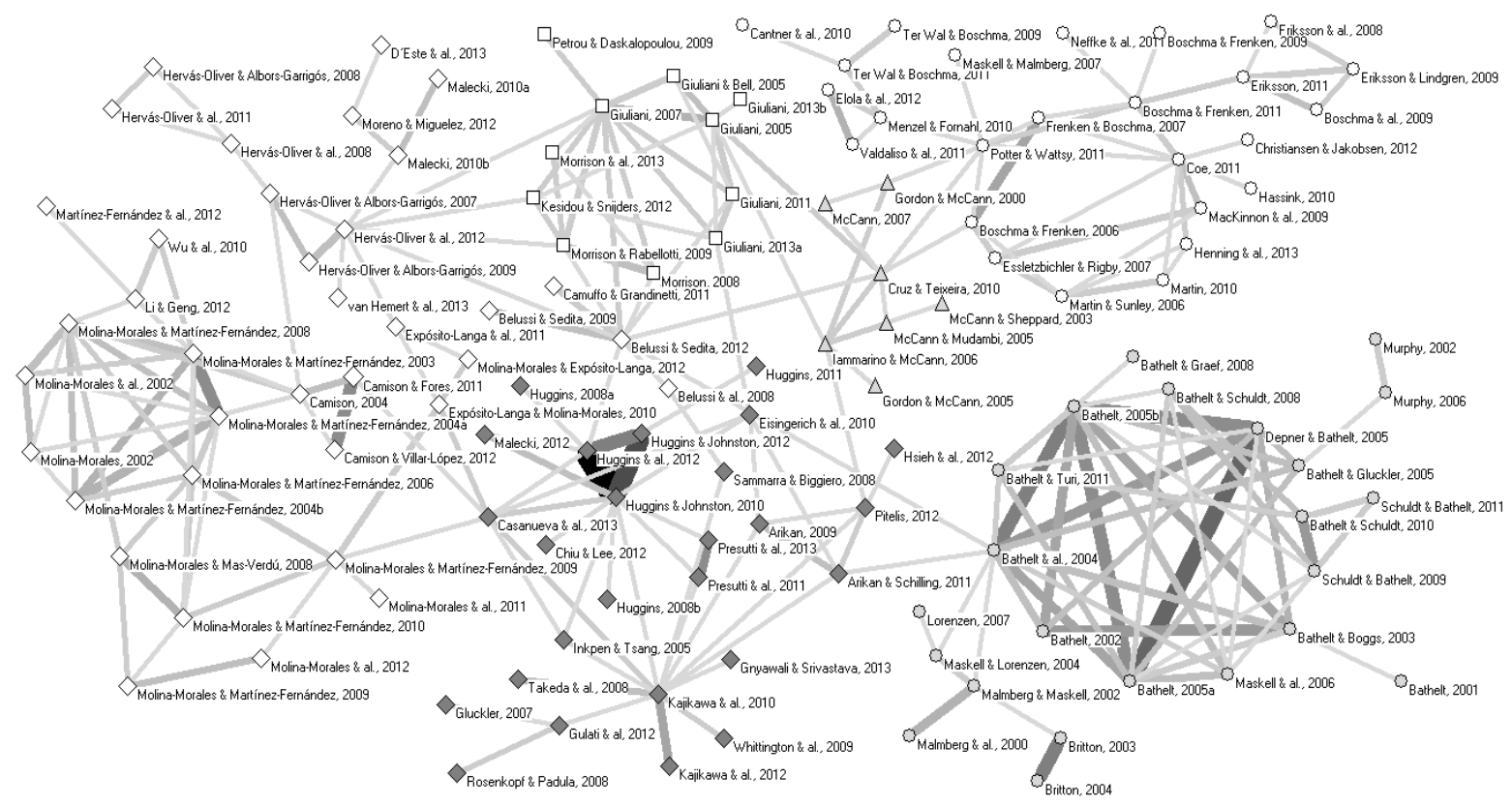

Source: authors' elaborations based on ISI database. The thickness of the lines reflects the frequency of references shared by a pair of nodes (documents). The symbols identify particular sub-groups. The names attached to each node refer to first and second authors and the year of publication.

Figure 4. Networks of bibliographic coupling (frequency counts, 1957-2013): agglomerations and spinoffs

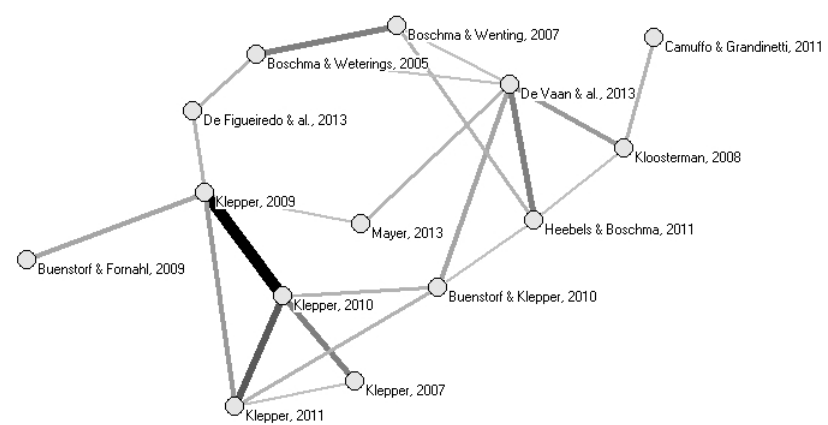

Source: authors' elaborations based on ISI database. The thickness of the lines reflects the frequency of references shared by a pair of nodes (documents). The names attached to each node refer to first and second authors and the year of publication. 
Figure 5. Networks of bibliographic coupling (frequency counts, 1957-2013): agglomerations and firm performance

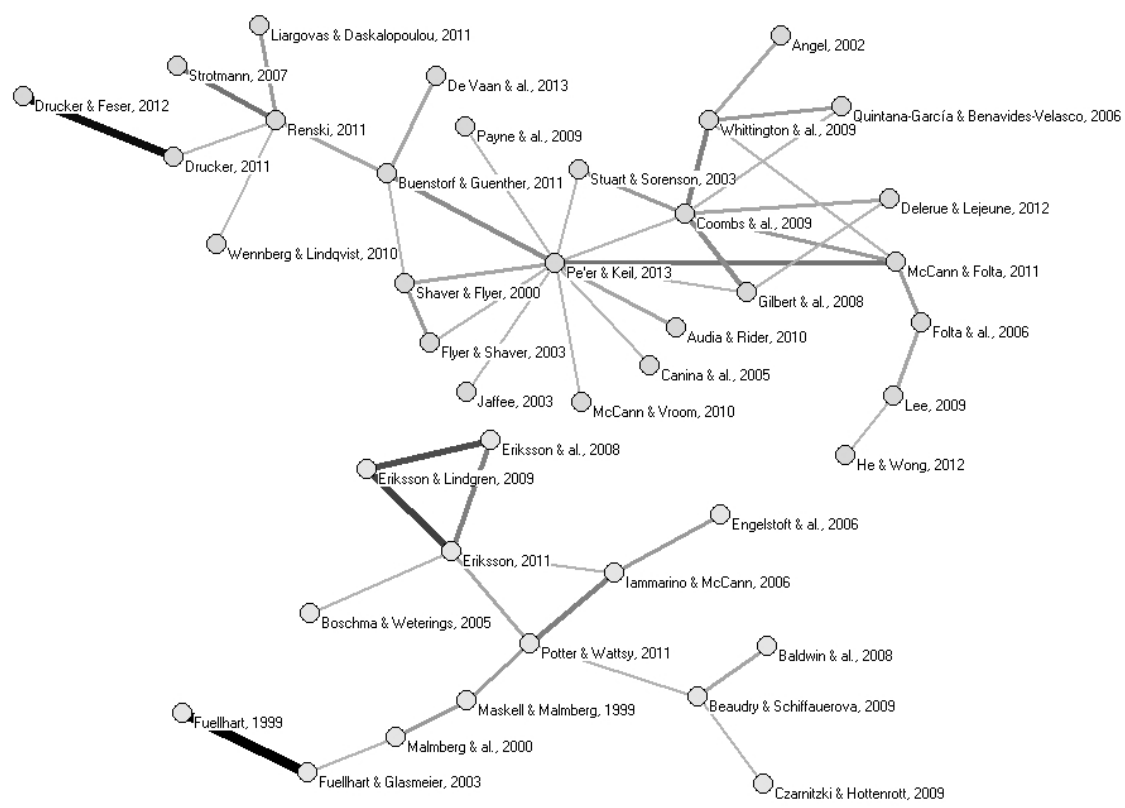

Source: authors' elaborations based on ISI database. The thickness of the lines reflects the frequency of references shared by a pair of nodes (documents). The names attached to each node refer to first and second authors and the year of publication. 
Table 1. Groups of citing documents, thematic titles, and symbols based on the bibliographic coupling from the first search: 1957-2013

\begin{tabular}{|c|c|c|c|c|c|}
\hline Group & Symbol & $\begin{array}{l}\text { Thematic } \\
\text { titles for the } \\
\text { scholarly } \\
\text { discourses }\end{array}$ & $\begin{array}{l}\text { Most references shared in each group } \\
\text { (cited references in the sub-fields; hierarchical } \\
\text { order*) }\end{array}$ & $\begin{array}{c}\text { Academic } \\
\text { Approach } \\
\text { based on citing } \\
\text { documents and } \\
\text { shared } \\
\text { references } \\
\end{array}$ & $\begin{array}{c}\text { Type of academic } \\
\text { journals in } \\
\text { each scholar conversation } \\
\text { (where citing documents } \\
\text { are published) }\end{array}$ \\
\hline 1 & O & $\begin{array}{l}\text { Evolutionary } \\
\text { economic } \\
\text { geography } \\
\text { E.g. Boschma } \\
\text { and Frenken, } \\
2011\end{array}$ & $\begin{array}{c}\text { Martin R, 2006, V6, P395, J Econ Geogr } \\
\text { Boschma RA, 2006, V6, P273, J Econ Geogr } \\
\text { Maskell P, 2007, V7, P603, J Econ Geogr } \\
\text { Nelson R R, 1982, Evolutionary Theory } \\
\text { Bathelt H, 2004, V28, P31, Prog Hum Geog } \\
\text { Jacobs J, 1969, Ec Cities } \\
\text { Storper M, 1989, Capitalist Imperativ } \\
\text { Frenken K, 2007, V41, P685, Reg Stud } \\
\text { Grabher G, 1993, P255, Embedded Firm Socioe } \\
\text { Boschma RA, 2004, V38, P1001, Reg Stud } \\
\text { Boschma RA, 2007, V16, P213, Ind Corp Change } \\
\text { Boschma RA, 1999, V9, P411, J Evol Econ }\end{array}$ & $\begin{array}{l}\text { Evolutionary } \\
\text { economic } \\
\text { geography and } \\
\text { regional studies } \\
\text { based }\end{array}$ & $\begin{array}{l}\text { Economic Geography, } \\
\text { Journal of Economic } \\
\text { Geography, Regional } \\
\text { Studies, among others. }\end{array}$ \\
\hline 2 & • & $\begin{array}{l}\text { Global } \\
\text { pipelines } \\
\text { E.g. Bathelt et } \\
\text { al., } 2004\end{array}$ & $\begin{array}{l}\text { Storper M, 1997, Regional World Terri } \\
\text { Grabher G, 2002, V36, P205, Reg Stud } \\
\text { Maskell P, 2001, V10, P921, Ind Corp Change } \\
\text { Maskell P, 1999, V23, P167, Cambridge J Econ } \\
\text { Uzzi B, 1997, V24, P35, Admin Sci Quart } \\
\text { Storper M, 2004, V4, P351, J Econ Geogr } \\
\text { Bathelt H, 2004, V28, P31, Prog Hum Geog } \\
\text { Scott A, 1988, New Ind Spaces Flexi } \\
\text { Porter M, 1990, Competitive Advantag } \\
\text { Granovetter M, 1985, V91, P481, Am J Sociol } \\
\text { Malmberg A, 2002, V34, P429, Environ Plann A } \\
\text { Maskell P, 1999, V6, P9, Eur Urban Reg Stud }\end{array}$ & $\begin{array}{c}\text { Economic } \\
\text { geography and } \\
\text { regional studies } \\
\text { based }\end{array}$ & $\begin{array}{l}\text { Journal of Economic } \\
\text { Geography, Progress in } \\
\text { Human Geography, } \\
\text { Environment and Planning } \\
\text { A, among others }\end{array}$ \\
\hline 3 & $\triangle$ & $\begin{array}{l}\text { Cluster } \\
\text { taxonomies } \\
\text { E.g. Gordon } \\
\text { and McCann, } \\
2000\end{array}$ & $\begin{array}{c}\text { GranovetMs, 1973, V78, P1360, Am J Sociol } \\
\text { Gordon IR, 2000, V37, P513, Urban Stud } \\
\text { Castells M, 1994, Technopoles World Ma } \\
\text { Nelson R R, 1982, Evolutionary Theory } \\
\text { Williamson O, 1975, Markets Hierarchies } \\
\text { Scott AJ, 1988, New Ind Spaces } \\
\text { Porter M, 1990, Competitive Advantag } \\
\text { Jaffe AB, 1993, V108, P577, Q J Econ } \\
\text { Vernon R, 1966, V80, P190, Q J Econ }\end{array}$ & $\begin{array}{c}\text { Economic } \\
\text { geography and } \\
\text { regional studies } \\
\text { based }\end{array}$ & $\begin{array}{l}\text { Urban Studies, Research } \\
\text { Policy, among others }\end{array}$ \\
\hline
\end{tabular}

Most cited 50 references in the first search from the 129 final documents (hierarchical order*, restricted to the output in the six groups

Cohen WM, 1990, V35, P128, Admin Sci Quart Bathelt H, 2004, V28, P31, Prog Hum Geog

Porter M, 1990, Competitive Advantag

Maskell P, 1999, V23, P167, Cambridge J Econ

Nelson R R, 1982, Evolutionary Theory

Granovetter M, 1985, V91, P481, Am J Sociol

Mcevily B, 1999, V20, P1133, Strategic Manage J Maskell P, 2001, V10, P921, Ind Corp Change Uzzi B, 1997, V42, P35, Admin Sci Quart GranovetMs, 1973, V78, P1360, Am J Sociol Giuliani E, 2005, V34, P47, Res Policy Uzzi B, 1996, V61, P674, Am Sociol Rev Storper M, 2004, V4, P351, J Econ Geogr Malmberg A, 2002, V34, P429, Environ Plann A Lawson C, 1999, V33, P305, Reg Stud Becattini G, 1990, P37, Ind Districts Interf Lawson C, 1999, V23, P151, Camb J Econ Boschma RA, 2005, V39, P61, Reg Stud Jaffe AB, 1993, V108, P577, Q J Econ Storper M, 1997, Regional World Terri

Marshall A, 1920, Principles Ec Saxenian A, 1994, Regional Advantage C Capello R, 1999, V33, P353, Reg Stud Boschma RA, 2006, V6, P273, J Econ Geogr Martin R, 2003, V3, P5, J Econ Geogr 


\begin{tabular}{|c|c|c|c|c|c|c|}
\hline 4 & $\diamond$ & $\begin{array}{l}\text { Innovation and } \\
\text { firm analysis } \\
\text { E.g. Belussi } \\
\text { and Sedita, } \\
2009\end{array}$ & $\begin{array}{c}\text { Becattini G, 1990, P37, Ind Districts Interf } \\
\text { Cohen WM, 1990, V35, P128, Admin Sci Quart } \\
\text { Maskell P, 1999, V23, P167, Cambridge J Econ } \\
\text { Uzzi B, 1996, V61, P674, Am Sociol Rev } \\
\text { Lazerson M H, 1999, V8, P235, Ind Corp Change } \\
\text { Foss NJ, 1996, V3, P1, J Ind Studies } \\
\text { Uzzi B, 1997, V42, P35, Admin Sci Quart } \\
\text { Porter M, 1990, Competitive Advantag } \\
\text { Pouder R, 1996, V21, P1192, Acad Manage Rev } \\
\text { Lawson C, 1999, V23, P151, Camb J Econ } \\
\text { Granovetter M, 1985, V91, P481, Am J Sociol } \\
\text { Decarolis DM, 1999, V20, P953, Strategic Manage J } \\
\text { Glasmeier A, 1991, V20, P469, Res Policy } \\
\text { Tsai WP, 1998, V41, P464, Acad Manage J }\end{array}$ & $\begin{array}{l}\text { Intersection } \\
\text { between } \\
\text { economic } \\
\text { geography and } \\
\text { management/in } \\
\text { novation }\end{array}$ & $\begin{array}{l}\text { Predominantly economic } \\
\text { geography-based: } \\
\text { European Planning } \\
\text { Studies, Entrepreneurship } \\
\text { and Regional } \\
\text { Development, Regional } \\
\text { Studies }\end{array}$ & $\begin{array}{l}\text { Krugman P, 1991, Geography Trade } \\
\text { Powell WW, 1996, V41, P116, Admin Sci Quart } \\
\text { Markusen A, 1996, V72, P293, Econ Geogr } \\
\text { Almeida P, 1999, V45, P905, Manage Sci } \\
\text { Lazerson M H, 1999, V8, P235, Ind Corp Change } \\
\text { Pouder R, 1996, V21, P1192, Acad Manage Rev } \\
\text { Porter ME, 1998, V76, P77, Harvard Bus Rev } \\
\text { Storper M, 1995, V2, P191, European Urban Regio }\end{array}$ \\
\hline 5 & $\diamond$ & $\begin{array}{l}\text { Inter-firm } \\
\text { networks, } \\
\text { social capital } \\
\text { and flows of } \\
\text { knowledge } \\
\text { E.g. } \\
\text { Eisingerich et } \\
\text { al., 2010 or } \\
\text { Glückler 2007 }\end{array}$ & $\begin{array}{c}\text { Cohen WM, 1990, V35, P128, Admin Sci Quart } \\
\text { Powell WW, 1996, V41, P116, Admin Sci Quart } \\
\text { Mcevily B, 1999, V20, P1133, Strategic Manage J } \\
\text { Dyer JH, 1998, V23, P660, Acad Manage Rev } \\
\text { Ahuja G, 2000, V45, P425, Admin Sci Quart } \\
\text { Bathelt H, 2004, V28, P31, Prog Hum Geog } \\
\text { Gulati R, 2000, V21, P203, Strategic Manage J } \\
\text { Burt R S, 1992, Structural Holes Soc } \\
\text { Owen-Smith J, 2004, V15, P5, Organ Sci } \\
\text { Gulati R, 1999, V20, P397, Strategic Manage J } \\
\text { Zaheer A, 2005, V26, P809, Strategic Manage J } \\
\text { Marshall A, 1920, Principles Ec } \\
\text { Saxenian A, 1994, V128, Regional Advantage C } \\
\text { Porter M, 1990, Competitive Advantag } \\
\text { Lawson C, 1999, V33, P305, Reg Stud } \\
\text { Tallman S, 2004, V29, P258, Acad Manage Rev } \\
\end{array}$ & $\begin{array}{l}\text { Predominantly } \\
\text { management } \\
\text { and } \\
\text { Intersection } \\
\text { between } \\
\text { management/in } \\
\text { novation and } \\
\text { economic } \\
\text { geography }\end{array}$ & $\begin{array}{c}\text { Management (e.g. } \\
\text { Organization Science, } \\
\text { Academy of Management } \\
\text { Review, Administrative } \\
\text { Science Quarterly), } \\
\text { innovation (Technovation, } \\
\text { Research Policy) and } \\
\text { economic } \\
\text { geography/regional studies } \\
\text { ones (e.g. Economic } \\
\text { Geography, Journal of } \\
\text { Economic Geography, } \\
\text { Regional Studies, } \\
\text { Entrepreneurship and } \\
\text { Regional Development) } \\
\end{array}$ & $\begin{array}{l}\text { Gordon IR, 2000, V37, P513, Urban Stud } \\
\text { Audretsch DB, 1996, V86, P630, Am Econ Rev } \\
\text { Tallman S, 2004, V29, P258, Acad Manage Rev } \\
\text { Martin R, 2006, V6, P395, J Econ Geogr } \\
\text { Ahuja G, 2000, V45, P425, Admin Sci Quart } \\
\text { Giuliani E, 2007, V7, P139, J Econ Geogr } \\
\text { Lane PJ, 1998, V19, P461, Strategic Manage J } \\
\text { Rowley T, 2000, V21, P369, Strategic Manage J } \\
\text { Dyer JH, 1998, V23, P660, Acad Manage Rev } \\
\text { Harrison B, 1992, V26, P469, Reg Stud }\end{array}$ \\
\hline 6 & $\square$ & $\begin{array}{l}\text { Network- } \\
\text { position } \\
\text { analysis and } \\
\text { technological } \\
\text { gatekeepers } \\
\text { E.g. Giuliani, } \\
2013\end{array}$ & $\begin{array}{l}\text { Von Hippel E, 1987, V16, P291, Res Policy } \\
\text { Cohen WM, 1990, V35, P128, Admin Sci Quart } \\
\text { Nelson R R, 1982, Evolutionary Theory } \\
\text { Giuliani E, 2005, V34, P47, Res Policy } \\
\text { Wasserman S, 1994,, Social Network Anal } \\
\text { Carter AP, 1989, V18, P155, Res Policy } \\
\text { Audretsch DB, 1996, V86, P630, Am Econ Rev } \\
\text { Lazerson M H, 1999, V8, P235, Ind Corp Change } \\
\text { Giuliani E, 2007, V7, P139, J Econ Geogr } \\
\text { Lissoni F, 2001, V30, P1479, Res Policy } \\
\text { Becattini G, 1990, P37, Ind Districts Interf } \\
\text { Bathelt H, 2004, V28, P31, Prog Hum Geog } \\
\text { Schrader S, 1991, V20, P153, Res Policy } \\
\text { Dosi G, 1988, V26, P1120, J Econ Lit } \\
\text { Capello R, 2005, V39, P75, Reg Stud } \\
\text { Boschma RA, 2005, V39, P61, Reg Stud } \\
\end{array}$ & $\begin{array}{c}\text { Economic } \\
\text { geography and } \\
\text { innovation } \\
\text { strand }\end{array}$ & $\begin{array}{l}\text { Economic Geography, } \\
\text { Journal of Economic } \\
\text { Geography, Regional } \\
\text { Studies, plus innovation } \\
\text { ones (Industry and } \\
\text { Innovation, Research } \\
\text { Policy) }\end{array}$ & $\begin{array}{c}\text { Owen-Smith J, 2004, V15, P5, Organ Sci } \\
\text { Breschi S, 2001, V10, P975, Ind Corp Change } \\
\text { Keeble D, 1999, V33, P295, Reg Stud } \\
\text { Piore Michael J, 1984, } 2 \text { Ind Divide Possibi } \\
\text { Lundvall B A, 1992, Natl Systems Innovat }\end{array}$ \\
\hline Total & & & & & & \\
\hline
\end{tabular}

Source: own, based on statistical cluster calculations over 3,955 documents in the first search; * for number of times cited, available upon request 
Table 2. Articles (citing documents) in each subfield of research from first search (Figure 3)

\begin{tabular}{|c|c|c|c|}
\hline Group 1. Evolutionary economic geography & Group 2. Global pipelines & $\begin{array}{l}\text { Group 5. Inter-firm networks, social } \\
\text { capital and flows of knowledge }\end{array}$ & Group 4. Innovation and firm analysis \\
\hline Boschma et al., (2009) & Bathelt et al., (2004) & $\begin{array}{l}\text { Arikan and Schilling, (2011) } \\
\end{array}$ & $\begin{array}{l}\text { Belussi and Sedita, (2009) } \\
\end{array}$ \\
\hline Boschma and Frenken, (2006) & Bathelt and Gluckler, (2005) & Arikan, (2009) & Belussi and Sedita, (2012) \\
\hline Boschma and Frenken, (2009) & Bathelt and Boggs, (2003) & Casanueva et all., (2013) & Belussi et al., (2008) \\
\hline Boschma and Frenken, (2011) & Bathelt and Graef, (2008) & Chiu and Lee, (2012) & Camison and Fores, (2011) \\
\hline Cantner et al., (2010) & Bathelt and Schuldt, (2008) & Eisingerich et al., (2010) & Camison and Villar-Lopez, (2012) \\
\hline Christiansen and Jakobsen, (2012) & Bathelt and Schuldt, (2010) & Glueckler, (2007) & Camison, (2004) \\
\hline Coe, (2011) & Bathelt and Turi (2011) & Gnyawali and Srivastava, (2013) & Camuffo and Grandinetti, (2009) \\
\hline Elola et al., (2012) & Bathelt, (2001) & Gulati et al., (2012) & D'Este et al., (2013) \\
\hline Eriksson and Lindgren, (2009) & Bathelt, (2002) & Hsieh et al., (2012) & Exposito-Langa and Xavier Molina-Morales, (2010) \\
\hline Eriksson et al., (2008) & Bathelt, (2005) & Huggins and Johnston, (2010) & Exposito-Langa et al., (2011) \\
\hline Eriksson, (2011) & Bathelt, (2005) & Huggins and Johnston, (2012) & Hervas-Oliver and Albors-Garrigos, (2007) \\
\hline Essletzbichler and Rigby, (2007) & Britton, (2003) & Huggins et al., (2012) & Hervas-Oliver and Albors-Garrigos, (2008) \\
\hline Frenken and Boschma (2007) & Britton, (2004) & Huggins, (2008) & Hervas-Oliver and Albors-Garrigos, (2009) \\
\hline Hassink, (2010) & Depner and Bathelt, (2005) & Huggins, (2008) & Hervas-Oliver et al., (2008) \\
\hline Henning et al., (2013) & Lorenzen, (2007) & Huggins, (2011) & Hervas-Oliver et al., (2011) \\
\hline Mackinnon et al., (2009) & Malmberg and Maskell, (2002) & Inkpen and Tsang, (2005) & Hervas-Oliver et al., (2012) \\
\hline Martin and Sunley, (2006) & Malmberg et al., (2000) & Kajikawa et al., (2010) & Li and Geng, (2012) \\
\hline Martin, (2010) & Maskell and Lorenzen, (2004) & Kajikawa et al., (2012) & Malecki, (2010a) \\
\hline Maskell and Malmberg, (2007) & Maskell et all., (2006) & Malecki,(2012) & Malecki, (2010b) \\
\hline Menzel and Fornahl, (2010) & Murphy, (2002) & Pitelis, (2012) & Martinez-Fernandez et al., (2012) \\
\hline Neffke et al., (2011) & Murphy, (2006) & Presutti et al., (2011) & Molina-Morales and Exposito-Langa, (2012) \\
\hline Potter and Watts, (2011) & Schuldt and Bathelt, (2009) & Presutti et al., (2013) & Molina-Morales and Martines-Fernandez, (2009) \\
\hline Ter Wal and Boschma, (2009) & Schuldt and Bathelt, (2011) & Rosenkopf and Padula, (2008) & Molina-Morales and Martinez-Fernandez, (2003) \\
\hline Ter Wal and Boschma, (2011) & & Sammarra and Biggiero, (2008) & Molina-Morales and Martinez-Fernandez, (2004a) \\
\hline \multirow[t]{2}{*}{ Valdaliso et al., (2011) } & & Takeda et al., (2008) & Molina-Morales and Martinez-Fernandez, (2004b) \\
\hline & & Whittington et al., (2009) & Molina-Morales and Martinez-Fernandez, (2006) \\
\hline \multirow[b]{2}{*}{ Group 3. Cluster taxonomies } & & & Molina-Morales and Martinez-Fernandez, (2008) \\
\hline & Group 6. Network-position analysis & & Molina-Morales and Martinez-Fernandez, (2009) \\
\hline Cruz and Teixeira, (2010) & Giuliani and Bell, (2005) & & Molina-Morales and Martinez-Fernandez, (2010) \\
\hline Gordon and McCann, (2000) & Giuliani, (2005) & & Molina-Morales and Mas-Verdu, (2008) \\
\hline Gordon and McCann, (2005) & Giuliani, (2011) & & Molina-Morales et al., (2002) \\
\hline Iammarino and McCann, (2006) & Giuliani, (2013a) & & Molina-Morales et al., (2011) \\
\hline McCann and Mudambi, (2005) & Giuliani, (2013b) & & Molina-Morales et al., (2012) \\
\hline McCann and Sheppard, (2003) & Giuliani,(2007) & & Molina-Morales, (2002) \\
\hline \multirow[t]{5}{*}{ Mccann,(2007) } & Kesidou and Snijders, (2012) & & Moreno and Miguelez, (2012) \\
\hline & Morrison and Rabellotti, (2009) & & van Hemert et al., (2013) \\
\hline & Morrison et al., (2013) & & Wu et al., (2010) \\
\hline & Morrison, (2008) & & \\
\hline & Petrou and Daskalopoulou, (2009) & & \\
\hline
\end{tabular}

Source:own, based on the second search 
Table 3. Articles of Figure 4, Figure 5

\begin{tabular}{|c|c|c|}
\hline $\begin{array}{l}\text { Figure 4. Agglomerations } \\
\text { and Spinoffs }\end{array}$ & \multicolumn{2}{|c|}{ Figure 5. Agglomerations and firm performance } \\
\hline Boschma and Weterings, (2005) & A. sub-field of 27 articles & $\begin{array}{l}\text { B. sub-field of } 14 \\
\text { articles }\end{array}$ \\
\hline Boschma and Wenting, (2007) & Angel, (2002) & Baldwin et al., (2008) \\
\hline Buenstorf and Fornahl, (2009) & Audia and Rider, (2010) & $\begin{array}{l}\text { Beaudry and } \\
\text { Schiffauerova, (2009) }\end{array}$ \\
\hline Buenstorf and Kleeper, (2010) & $\begin{array}{l}\text { Buenstorf and Guenther, } \\
\text { (2011) }\end{array}$ & $\begin{array}{l}\text { Boschma and Weterings, } \\
\text { (2005) }\end{array}$ \\
\hline Camuffo and Grandinetti, (2011) & Canina et al., (2005) & $\begin{array}{l}\text { Czarnitzki and } \\
\text { Hottenrott, (2009) }\end{array}$ \\
\hline De Figueiredo et all., (2013) & Coombs et al., (2009) & Engelstoft et at., (2006) \\
\hline De Vaan et al., (2013) & De Vaan et al., (2013) & $\begin{array}{l}\text { Eriksson and Lindgren, } \\
\text { (2009) }\end{array}$ \\
\hline $\begin{array}{l}\text { Heebels and Boschma, (2011) } \\
\text { Klepper, (2007) }\end{array}$ & $\begin{array}{l}\text { Delerue and Lejeune, (2012) } \\
\text { Drucker and Feser, (2012) }\end{array}$ & $\begin{array}{l}\text { Eriksson et al., (2008) } \\
\text { Eriksson, (2011) }\end{array}$ \\
\hline Klepper, (2009) & Drucker, (2011) & $\begin{array}{l}\text { Fuellhart and Glasmeier, } \\
\text { (2003) }\end{array}$ \\
\hline Klepper, (2010) & Flyer and Shaver, (2003) & Fuellhart, (1999) \\
\hline Klepper, (2011) & Folta et al., (2006) & $\begin{array}{l}\text { Iammarion and McCann, } \\
\text { (2006) }\end{array}$ \\
\hline Kloosterman, (2008) & Gilbert et al, (2008) & Malmberg et al., (2000) \\
\hline Mayer, (2013) & He and Wong, (2012) & $\begin{array}{l}\text { Maskell and Malmberg, } \\
\text { (1999) }\end{array}$ \\
\hline & $\begin{array}{l}\text { Jaffee, (2003) } \\
\text { Lee, (2009) } \\
\text { Liargovas and } \\
\text { Daskalopoulou, (2011) } \\
\text { McCann and Folta, (2011) } \\
\text { McCann and Vroom, (2010) } \\
\text { Payne et al., (2009) } \\
\text { Pe'er and Keil, (2013) } \\
\text { Quintana-García and } \\
\text { Benavides-Velasco, (2006) } \\
\text { Renski, (2011) } \\
\text { Shaver and Flyer, (2000) } \\
\text { Strotmann, (2007) } \\
\text { Stuart and Sorenson, (2003) } \\
\text { Wennberg and Lindqvist, } \\
\text { (2010) } \\
\text { Whittington et al., (2009) } \\
\end{array}$ & Potter and Watts, (2011) \\
\hline
\end{tabular}

Source: own; from the second search (1957-2013). More documents from the second search available upon 


\section{Appendix}

Table A-1. First fifteen most cited papers (shared references) in the documents constitutive of the first search (industrial districts and clusters;1957-2013)

\begin{tabular}{|l|c|}
\hline References & N times cited \\
\hline Porter M, 1990, Competitive Advantag & 489 \\
\hline Bathelt H, 2004, V28, P31, Prog Hum Geog & 313 \\
\hline Krugman P, 1991, Geography Trade & 279 \\
\hline Porter ME, 1998, V76, P77, Harvard Bus Rev & 261 \\
\hline Cohen WM, 1990, V35, P128, Admin Sci Quart & 255 \\
\hline Martin R, 2003, V3, P5, J Econ Geogr & 247 \\
\hline Marshall A, 1920, Principles Ec & 240 \\
\hline Saxenian A, 1994, Regional Advantage C & 230 \\
\hline Markusen A, 1996, V72, P293, Econ Geogr & 224 \\
\hline Nelson R R, 1982, Evolutionary Theory & 220 \\
\hline Granovetter M, 1985, V91, P481, Am J Sociol & 212 \\
\hline Storper M, 1997, Regional World Terri & 208 \\
\hline Audretsch DB, 1996, V86, P630, Am Econ Rev & 199 \\
\hline Lundvall B A, 1992, Natl Systems Innovat & 197 \\
\hline Jaffe AB, 1993, V108, P577, Q J Econ & 188 \\
\hline
\end{tabular}

Source: own, from the first search and database $(3,995)$; For the sake of brevity only 15 are showed. More results available upon request

Figure A-2. Growth of cluster/industrial district publications 1957-2013

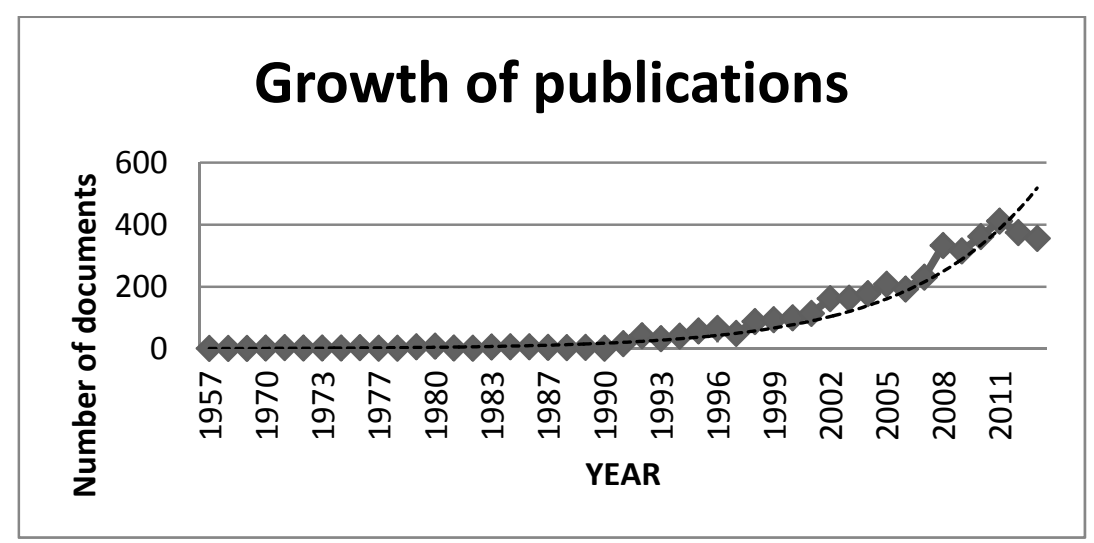

Source: ours, from analysis of Web of Science 
Figure A-3. The first twenty journals by number of articles listed in the first search (3,995 documents):

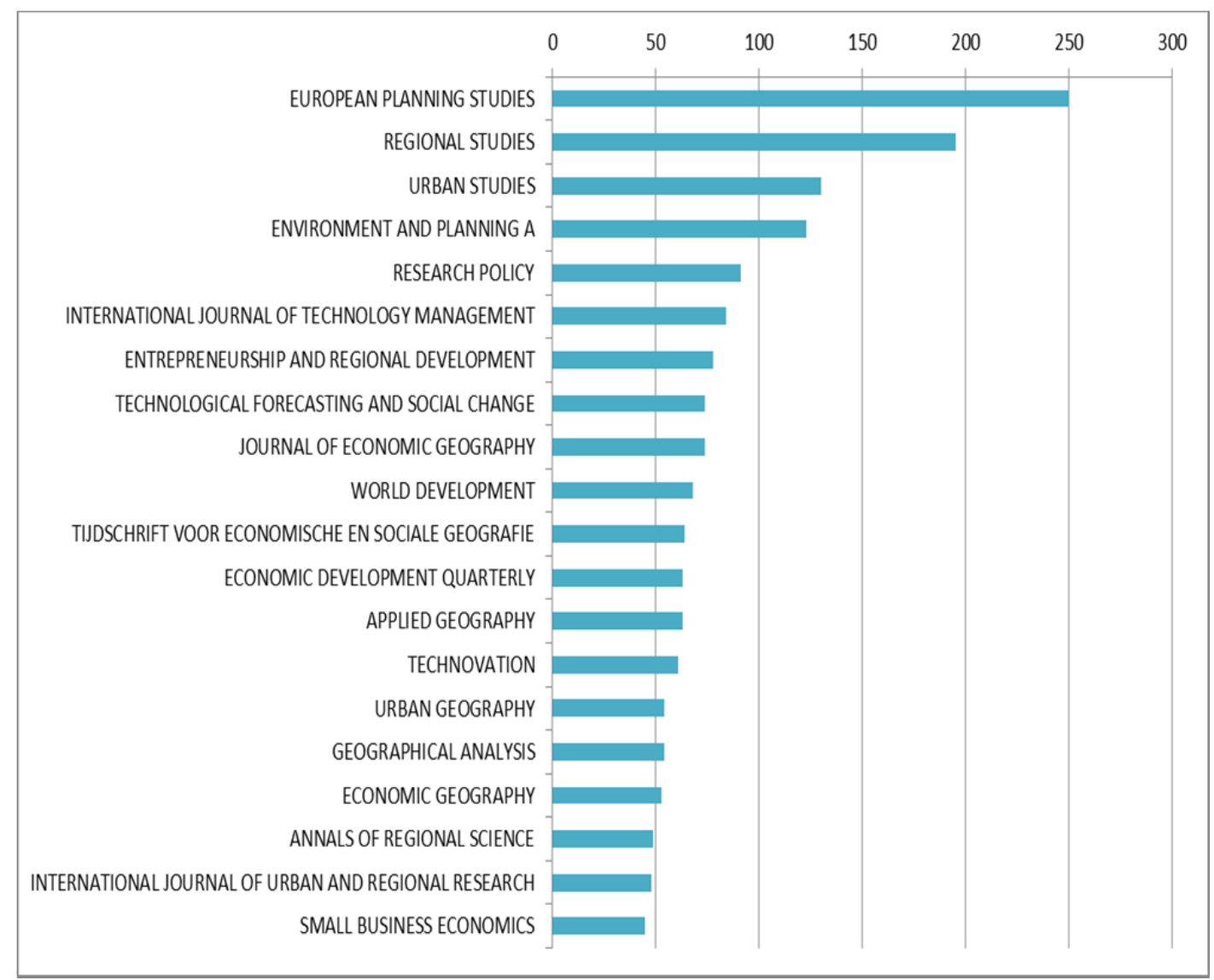

Source: own, from the first search

Table A-5. First fifteen most cited papers (shared references) in the documents constitutive of the second search (agglomerations;1957-2013)

\begin{tabular}{|l|r|}
\hline \multicolumn{1}{|c|}{ References } & N times cited \\
\hline Krugman P, 1991, V99, P483, J Polit Econ & 460 \\
\hline Krugman P., 1991, Geography Trade & 349 \\
\hline Glaeser EL, 1992, V100, P1126, J Polit Econ & 282 \\
\hline Venables, 1999, Spatial Ec Cities Re & 274 \\
\hline Porter M. E., 1990, Competitive Advantag & 273 \\
\hline Jaffe AB, 1993, V108, P577, Q J Econ & 231 \\
\hline Jacobs J., 1969, Ec Cities & 228 \\
\hline Marshall A, 1920, Principles Ec & 217 \\
\hline Ciccone A, 1996, V86, P54, Am Econ Rev & 200 \\
\hline Audretsch DB, 1996, V86, P630, Am Econ Rev & 196 \\
\hline Ellison G, 1997, V105, P889, J Polit Econ & 165 \\
\hline Dixit AK, 1977, V67, P297, Am Econ Rev & 164 \\
\hline Marshall A., 1890, Principles Ec & 162 \\
\hline Morgan K, 1997, V31, P491, Reg Stud & 160 \\
\hline Lundvall Bengt-Ake, 1992, Natl Systems Innovat & 159 \\
\hline
\end{tabular}

Source: own, from the second search and database $(2,419)$; not restricted to subsequent refinements (spinoffs or performance). For the sake of brevity only 15 are showed. More results available upon request 
Figure A-4. Academic journals by number of articles in the final 129 citing documents (first search).

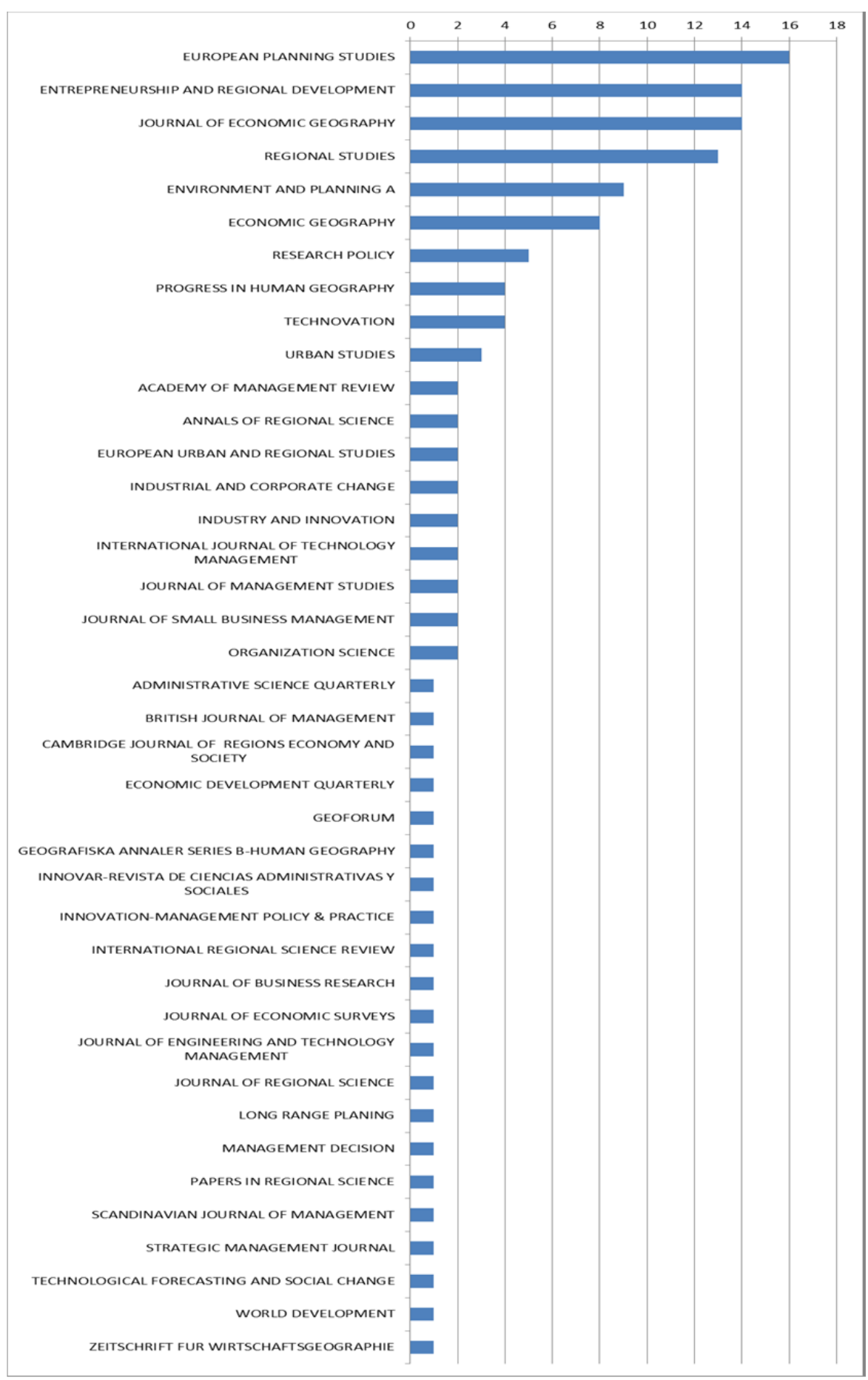

Source: own, from the first search 